\title{
Framework for a collaborative process to increase preparation for drought on U.S. public rangelands
}

\author{
Julie Brugger $^{1}$, Kelsey L. Hawkes ${ }^{1}$, Anne M. Bowen ${ }^{1}$ and Mitchel P. McClaran ${ }^{1}$
}

\begin{abstract}
We describe a theoretically based framework (C-PMT+HAPA) for designing and evaluating collaborative processes to increase preparation for natural hazards in situations in which preparedness decisions are shared and actions must be taken jointly by more than one party. The framework combines two health behavior change theories from psychology, protection motivation theory (PMT) and the health action process approach (HAPA), with collaboration theory in natural resources management. The framework provides much needed guidance for designing the activities in which participants will collaborate and suggests theoretically supported intermediate outcomes that may indicate a successful trajectory toward the ultimate goal of increased preparation. We used this framework in a collaborative process, with participation by ranchers with grazing permits and U.S. Forest Service managers on the Tonto National Forest, to increase preparation for drought on public rangelands in the Southwestern U.S. Evaluation of intermediate outcomes indicated: (1) improved interactions and relations between parties; (2) improved ability to appraise drought risks; (3) improved understanding of the U.S. Forest Service process for approving practices that increase preparation for drought; and; (4) increased motivation to implement these practices. The strength of the intermediate outcomes suggests that the C-PMT+HAPA framework would be an effective, theoretically supported framework for designing and evaluating collaborative processes to encourage preparation for natural hazards. More generally, the framework could contribute to more transdisciplinary, system- and action-oriented research on disaster risk reduction that is coproduced with multiple stakeholders.
\end{abstract}

Key Words: collaborative management; design and evaluation; drought planning; health action planning approach; natural hazards; protection motivation theory; scenario planning; social-ecological model; usable information

\section{INTRODUCTION}

Drought is an inevitable, but unpredictable, natural hazard affecting rangelands. Rangelands, defined as grasslands, shrublands, savannas, deserts, prairies, steppe, and tundra grazed by livestock, cover more of the Earth's surface (30-40\%) than any other type of land and contribute to the livelihoods of 1-2 billion people (Sayre et al. 2013, Reid et al. 2014). They are characterized by limited water and nutrients, low average production that is highly spatially and temporally variable, spatial heterogeneity in human management influences, and political and economic marginality (Havstad 2009, Savre et al. 2013, Reid et al. 2014, Derner and Augustine 2016). As complex social-ecological systems that include biophysical, economic, social, and institutional components, they are subject to many sources of uncertainty in addition to drought.

The complexity and uncertainty increase on public rangelands in the United States where ranchers and federal land management agencies share the responsibility to design and implement sustainable livestock grazing practices, but have different suites of priorities and different levels of power and authority. In addition, the majority of public rangelands are located in semiarid to arid regions of the western U.S. in which interannual climate variability is high, and topography and spatiotemporal variability of precipitation can create complex spatial patterns of drought (Havstad et al. 2009, McClaran and Wei 2014, Crimmins and McClaran, 2016).

Drought planning by U.S. livestock producers typically focuses on increasing operational flexibility by diversifying options for forage, water, and income, as well as adjusting herd management strategies and livestock genetics, and developing contingency plans for response (Coppock 2011, Knutson and Haigh 2013, Kachergis et al. 2014, Briske et al. 2015, Macon et al. 2016, Scasta et al. 2016). Public rangelands pose an additional level of planning complexity because the management decisions of ranchers with grazing permits are subject to agency regulations and policy, and agency decisions are subject to environmental impact analysis and public scrutiny as mandated by the 1969 National Environmental Policy Act. Proactive drought planning (Kelley et al. 2016) on public rangelands will require collaboration between agency officials, permittees, and other stakeholders.

A collaborative process that includes multiple stakeholders and integrates different types of knowledge is widely recognized as a promising approach to managing complex social-ecological systems with high levels of uncertainty and competing goals and values. Collaborative approaches have been used in the management of fisheries, forests, wildlife, rangelands, water resources, and protected areas (Conley and Moote 2001), less so in natural hazards planning (exceptions include Eriksen and Prior 2011, Reyers et al. 2015). The benefits claimed for such approaches include more relevant, effective, and democratic decisions, social learning, and increased social capital in the form of improved communication, relationships, and trust among stakeholders, and the development of social networks (Funtowicz and Ravetz 1993, Wondolleck and Yaffee 2000, Lachappelle et al. 2003, Robertson and Hull 2003, von Korff et al. 2010). Increased trust, social capital, and social learning also increase adaptive capacity and resilience to future management challenges (Stern and Baird 2015, Folke 2016). 
Fig. 1. Collaborative protection motivation theory + health action process approach (C-PMT+HAPA) framework for increasing protection motivation and action.

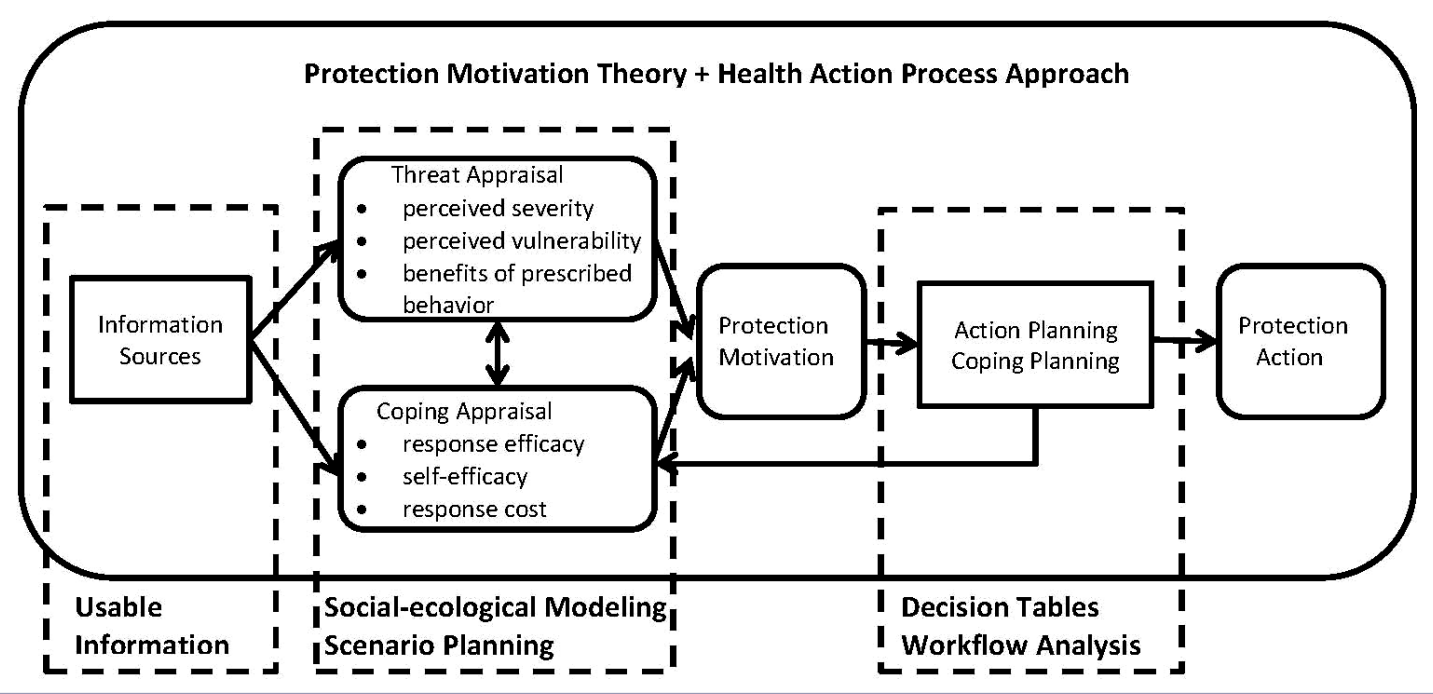

A growing literature in collaboration theory provides general principles for designing collaborative processes to increase their potential to realize these benefits (e.g., Ansell and Gash 2008, von Korff et al. 2010, Knapp et al. 2011, Reed et al. 2014, Talley et al. 2016). However, there is less systematic practical guidance for designing the interaction mechanism, or the specific activities in which participants in a collaborative process will engage, and for evaluating outcomes of the process (von Korff et al. 2010).

We describe a theoretically based framework that provides systematic practical guidance for designing the specific activities for a collaborative process to increase preparation for natural hazards and evaluating its outcomes and to provide an example of how we applied it to increase preparation for drought. We use the term "codevelopment" to refer to this type of collaborative process because participants in the process collaboratively develop practices that increase natural hazard preparedness and plans to implement them. The framework emerged from our experience with a codevelopment process to increase preparation for drought on public rangelands in the Southwestern U.S. We suggest that it can be used to foster increased preparation for other natural hazards in situations in which preparedness decisions are shared and actions must be taken jointly by more than one party. Such situations might include wildfire preparedness and climate change adaptation. It also contributes to a needed paradigm shift in disaster science because it provides a concrete method for "transdisciplinary system analysis" and "action-oriented research on disaster risk reduction" to be "co-produced with multiple stakeholders" (Ismail-Zadeh et al. 2017:969).

The framework combines two health behavior change theories from psychology: (1) protection motivation theory (PMT; Rogers 1975, Floyd et al. 2000) and the health action process approach (HAPA; Schwarzer 2008), with collaboration theory in natural resource management. We refer to the framework as Collaborative PMT+HAPA (C-PMT+HAPA). Protection motivation theory is a social cognitive model describing factors that motivate people to take protective actions. It has been used successfully in a variety of health contexts, as well as to understand what motivates people to increase preparedness for natural hazards such as floods, wildfire, drought, and climate change (e.g., Grothmann and Patt 2005, Grothmann and Reusswig 2006, Martin et al. 2007, Stewart 2009, Koerth et al. 2013, McClaran et al. 2015). These studies applied PMT to survey results to explain retroactively why some people acted and others did not. Health action process approach adds components of action and coping planning to bridge the gap between intention and behavior often overlooked in health behavior change theories. Protection motivation theory and HAPA have been combined successfully to promote exercise during pregnancy (Gaston and Prapavessis 2014). Together they conceptualized how individuals were motivated (PMT) and assisted in implementing actions (HAPA) advocated by health professionals to protect against health risks identified by those professionals (Floyd et al. 2000, Schwarzer 2008). We combine collaboration theory with PMT+ HAPA to address situations in which protective actions against the risk of a natural hazard must be taken jointly by more than one party. In those cases, we expect more effective outcomes when the risk is collaboratively appraised and practices to increase preparedness and plans to implement them are codeveloped. As far as we are aware, we describe the first time that PMT+HAPA have been designed for a collaborative setting, and the first time they have been used proactively to promote preparedness for natural hazards.

Improved preparation for a natural hazard is the ultimate expected outcome from a codevelopment process based on the CPMT+HAPA framework. However considerable time may have to pass before that outcome can be evaluated. An additional value of the framework is that it suggests theoretically supported intermediate outcomes that can be evaluated more rapidly, and it indicates a trajectory toward the ultimate goal.

\section{THE C-PMT+HAPA FRAMEWORK}

Figure 1 illustrates the C-PMT+HAPA framework for a codevelopment process to increase preparation for natural 
hazards. The solid boundary encloses a diagram of (modified) PMT+HAPA. Protection motivation theory suggests that motivation is a result of two cognitive processes, threat appraisal and coping appraisal. Within threat appraisal, individuals weigh the severity of the threat and perceived vulnerability to it against the benefits of adopting the protective behavior. The overall threat appraisal is then used in coping appraisal, in which individuals weigh the efficacy of the behavior (response efficacy) and the belief that he/she can perform it (self-efficacy) against the cost of performing it (Floyd et al. 2000, Stewart 2009). Threat appraisal and coping appraisal along with the emotion of fear give rise to protection motivation, or the intention to follow the recommendation. A wide variety of information sources can be used in threat and coping appraisals (Stewart 2009). However, in health interventions designed using PMT, information about the targeted health risks and recommended protective actions is provided by health professionals.

The HAPA is relevant because an intention to change did not necessarily lead to a change in behavior (Gaston and Prapavessis 2014). Therefore, the HAPA model adds a second phase that translates intention into action through action planning and coping planning (Schwarzer 2008). In action planning, individuals specify when, where, and how they will perform the recommended behavior; in coping planning, they develop plans to cope with scenarios that hinder them from performing the behavior.

Combining collaboration theory with PMT+HAPA suggests that when a group of actors rather than an individual is responsible for making preparedness decisions and taking actions, outcomes will improve when the group performs threat and coping appraisals and action and coping planning jointly. In C-PMT+ HAPA, threat appraisal involves collaborative appraisal of the frequency and severity of a natural hazard, its impacts, vulnerability to it, and the benefits of preparedness practices. Coping appraisal involves the codevelopment of preparedness practices that are perceived as effective, possible, and affordable.

We use two-way arrows (Fig. 1) to represent the iterative nature of the C-PMT+HAPA process because multiple coping practices may be codeveloped, and coping appraisal would be revisited to compare the benefits of each. In addition, action and coping planning involve collaboratively planning for the steps and timeline of a decision process to implement preparedness practices, and what to do if there is a setback. Therefore, an arrow has been added from action and coping planning back to coping appraisal because if the collaborative action and coping planning process is unsuccessful, participants may need to return to coping appraisal to choose a different preparedness practice to try and implement.

\section{STRUCTURING AND EVALUATING ACTIVITIES TO IMPLEMENT C-PMT+HAPA}

To enable collaboration at each step of the C-PMT+HAPA framework, we drew on additional bodies of theory and practice to design collaborative activities (dashed boxes in Fig. 1). Specifically, we included: (1) the coproduction of usable information to create more usable information for threat and coping appraisals; (2) social-ecological modeling and scenario planning to perform threat and coping appraisals jointly; and (3) decision table development and workflow analysis to perform action and coping planning jointly. In addition, we propose an evaluation approach that focuses on the intermediate outcomes expected from the combination of C-PMT+HAPA because it is too soon to observe long-term outcomes.

\section{Coproduction of useable information}

The C-PMT+HAPA framework draws on the coproduction of usable information (sometimes referred to as usable knowledge or usable science) to develop information for threat and coping appraisals rather than using information produced by professionals. The coproduction of usable information is a process of collaboration between scientists and decision makers with the goal of producing information that better fits the needs of decision makers (Lemos and Morehouse 2005, Dilling and Lemos 2011, Meadow et al. 2015). It responds to recognition of the shortcomings of a linear model of knowledge production in which scientists produce knowledge for decision makers without am understanding of the context of its use. Coproduced information is more likely to be accepted and used by decision makers if the spatial and temporal scales are useful to them and easier to integrate with existing information (Lemos and Morehouse 2005, Dilling and Lemos 2011, Meadow et al. 2015). To be effective, coproduction processes must involve building relationships between scientists and decision makers and ensuring two-way communication.

Lemos et al. (2012) identified three interconnected factors that affect the usability of climate information that we apply to the coproduced information to be used in threat and coping appraisals: (1) fit of the information to meet users' needs; (2) interaction between information producers and users; and (3) interplay between the new information and the social, political, and economic context of the management environment. Increasing fit, interplay, and interaction is expected to improve the usability of the information, which should improve threat and coping appraisals and potentially increase the likelihood of taking protective action.

\section{Social-ecological models and scenario planning}

The C-PMT+HAPA framework uses social-ecological modeling and scenario planning to facilitate participant engagement in threat and coping appraisals. A social-ecological model is a purposeful representation of a social-ecological system that uses abstraction and simplification to assist thinking about it. When there are high degrees of complexity and uncertainty in the system, models allow users to explore the consequences of management alternatives, which can improve decision making (Addison et al. 2013, Price et al. 2016). The use of models can also help improve communication, build trust and relationships, promote group learning, and provide opportunities for collaboration among users (Price et al. 2016).

These models provide opportunities for participants to engage in joint problem-solving in realistic natural hazard situations. The model should be able to reflect the effects of different severities of the natural hazard on the social-ecological system of interest and the effects of preparedness practices. For example, in our codevelopment process we used a model of a hypothetical, but realistic national forest grazing allotment. The model could be codeveloped by the participants, which can be time consuming. In our case, with limited time and a team with sufficient knowledge about the system and participants' perceptions of it, we developed the model. 
To structure the use of the social-ecological model, the framework uses scenario planning (also referred to as scenario analysis). Scenario planning is an approach used to inform longer-term decision making in situations of high uncertainty, complexity, and lack of control. It simplifies complex systems into multiple plausible future scenarios built around critical uncertainties. Decision makers evaluate these scenarios to develop strategic plans and management actions that are likely to increase preparation for a range of possible future conditions (Wollenberg et al. 2000, Weeks et al. 2011, Amer et al. 2013, Rowland et al. 2014).

Scenario planning facilitates group learning, strategic thinking, and knowledge coproduction among participants, and can improve decision making (Amer et al. 2013, Rowland et al. 2014, Reyers et al. 2015). It can also improve adaptive capacity by anticipating change, improving responsiveness and collaboration among participants, enabling articulation of risks and the values placed on consequences, and identifying alternatives that may avoid certain risks, reduce probability of their occurrence, or reduce negative consequences (Wollenberg et al. 2000, Amer et al. 2013, Rowland et al. 2014). There are a wide variety of approaches to scenario planning: the most commonly used is a process in which participants codevelop the scenarios, which can be time consuming (Rowland et al. 2014). In our case, the team developed scenarios.

\section{Decision tables and workflow analysis}

The C-PMT+HAPA framework uses collaborative construction of a decision table and workflow analysis to perform action and coping planning. Decision tables are used in system analysis and design to model complex decision logic by indicating what course of action will be taken for each value or combination of values of one or more variables or parameters that affect the decision (Kirk 1964). Rows represent the parameters that can affect the decision, and columns represent the possible values for these conditions. In action and coping planning in PMT+HAPA, individuals decide when, where, and how they will perform the desired behavior. In C-PMT+HAPA, this is a collaborative effort performed by the whole group, and each group may have its own decision process that must be negotiated to implement a preparedness practice. A collaboratively constructed decision table makes these decision processes explicit to all participants.

Once the decision table has been constructed, participants perform action and coping planning by using it to perform workflow analysis for implementing different types of preparedness practices, taking into consideration parameters that can affect the decision process and unexpected events that may disrupt it. Workflow analysis typically separates work activities in manufacturing and the office into well-defined tasks, roles, rules, and procedures with the goal of increasing efficiency (Georgakopoulos et al. 1995).

Collaboratively performing these analyses for natural hazards planning can contribute to a shared understanding of the steps and timeline necessary to implement a preparedness practice among participants. The analyses should also identify who will and how they will track the implementation process, communicate progress, and how they will respond to unexpected events. In our case, participants created a decision table and performed workflow analysis for the U.S. Forest Service (FS) decision process to approve a selected preparedness practice.

\section{Evaluation of intermediate outcomes}

The ultimate expected outcome of a codevelopment process based on the C-PMT+HAPA framework is the implementation of practices that improve preparation for a natural hazard. However, it may take considerable time for practices to be implemented and for researchers to be able to evaluate that outcome. A significant advantage of the C-PMT+HAPA framework is that it suggests theoretically supported intermediate outcomes that indicate a successful trajectory toward the ultimate outcome, which can be evaluated more rapidly. These are: (1) improved interactions and relations between the parties; (2) more usable information about the natural hazard; (3) improved threat appraisal; (4) the codevelopment of practices to increase preparation; (5) increased motivation to take protective action; and (6) the development of plans to implement preparedness practices. These generalized intermediate outcomes will take a more specific form for each application of the C-PMT+HAPA framework.

\section{APPLYING C-PMT+HAPA TO INCREASE PREPARATION FOR DROUGHT ON SOUTHWEST RANGELANDS}

An interdisciplinary coordinating team representing disciplines relevant to the specific application of the framework performs the task of designing collaborative activities that are tailored to that application for each step in the C-PMT+HAPA framework. The design of activities is an iterative process, similar to developmental evaluation (Patton 2010). The team conducts preliminary research to understand the participants and the context, and to develop an initial project design. The initial design is modified as the team incorporates ongoing learning from interactions, outcomes of activities, and evaluations into the design of activities for subsequent steps.

We illustrate how the C-PMT+HAPA framework can be used to design a codevelopment process to increase preparation for natural hazards. We used it to support the design, implementation, and evaluation of activities for a codevelopment process to increase preparation for drought on Southwest rangelands. The process unfolded in a series of three workshops in which ranchers and federal land management agency range managers collectively appraised the risk of drought on a hypothetical grazing allotment and codeveloped preparedness practices and plans to implement them. Preliminary research shaped our goal of providing an opportunity for participants to gain sufficient understanding and experience working together to carry out these activities on actual allotments. Table 1 shows a timeline of activities.

\section{Project setting and policy context}

The project took place between 2014 and 2016 on the Tonto National Forest (TNF), located primarily within Gila County in central Arizona, USA. The TNF lies within the Southwestern Region of the U. S. Forest Service (Region 3), which includes 11 national forests throughout Arizona and New Mexico. The TNF covers 1.2 million ha $\left(33^{\circ} 46^{\prime} 17^{\prime \prime} \mathrm{N}, 111^{\circ} 05^{\prime} 35^{\prime \prime} \mathrm{W}\right)$, spans from 500 to $2200 \mathrm{~m}$ elevation, and the corresponding average annual precipitation and annual temperatures range from 275 to $820 \mathrm{~mm}$ and 21 to $9{ }^{\circ} \mathrm{C}$. Desert scrub, grassland, woodland, and forest vegetation occur along this elevation-precipitation gradient. Precipitation is bimodally distributed, with $40 \%$ between the warm summer months of June and September. Summer convective storms are more spatially variable than winter frontal storms (McClaran and Wei 2014). Drought is projected to become 
Table 1. Timeline of codevelopment process to increase preparation for drought on public rangelands.

\begin{tabular}{|c|c|}
\hline Timeline & Activity \\
\hline Fall 2012 & $\begin{array}{l}\text { Preliminary analysis and design. } \\
\text { Interdisciplinary team with experience in cooperative extension, rangeland management, climatology, and social science methods } \\
\text { meets to plan workshop to explore interest in a codevelopment process to address the challenges of drought on public rangelands } \\
\text { in the Southwest USA. }\end{array}$ \\
\hline Feb 2013 & $\begin{array}{l}\text { Ranching with drought workshop includes ranchers from across Arizona, personnel from federal and state land-management } \\
\text { agencies, Natural Resources Conservation Service, and potential funding agencies, and University of Arizona research and } \\
\text { extension scientists and students. }\end{array}$ \\
\hline \multirow[t]{3}{*}{ Feb-Nov 2013} & $\begin{array}{l}\text { Team meets to develop proposal to National Oceanic and Atmospheric Administration Sectoral Application Research Program } \\
\text { based on insights gained from workshop. }\end{array}$ \\
\hline & $\begin{array}{l}\text { Workshop participants recommended situating project in Tonto National Forest (TNF). Participants to include district rangers, } \\
\text { range staff, and ranchers with grazing permits on the TNF. }\end{array}$ \\
\hline & $\begin{array}{l}\text { Elicited support for project from U.S. Forest Service (FS) Region } 3 \text { Director of Rangeland Management, TNF supervisor, Gila } \\
\text { County Cattle Growers Association (GCCGA), and Arizona Cattle Growers Association (ACGA). }\end{array}$ \\
\hline \multirow{2}{*}{ Nov 2013} & Proposal submitted. \\
\hline & Ongoing analysis and design. \\
\hline Aug 2014 & Proposal funded and project initiated. \\
\hline Aug 2014-Feb 2016 & $\begin{array}{l}\text { Team meets regularly to plan workshops and integrate knowledge from ongoing context and stakeholder analysis. } \\
\text { Team benefits from social capital of team member in cooperative extension who worked with ranchers and FS on range } \\
\text { monitoring and other livestock management related projects in Gila County for } 20 \text { years. }\end{array}$ \\
\hline Nov-Dec 2014 & $\begin{array}{l}\text { Conduct survey to determine stakeholder views and levels of trust and conflict. Results indicate that ranchers and FS see each } \\
\text { other as the most important factor creating risk. } \\
\text { Summarize and clarify FS policy and decision process for livestock management. }\end{array}$ \\
\hline Dec-Jan 2014 & $\begin{array}{l}\text { Participants to include all district rangers and range staff, forest supervisor, and forest-wide range staff from TNF. Ranchers } \\
\text { selected based on indicated interest in survey, location of allotment to represent all districts, and recommendation by Gila County } \\
\text { extension director, FS, or GCCGA. }\end{array}$ \\
\hline \multirow[t]{2}{*}{ Jan-Mar 2015} & Conduct in-depth interviews with all FS and rancher participants. \\
\hline & $\begin{array}{l}\text { Schedule workshops in alternate locations and at times that did not conflict with rancher and FS seasonal activities. } \\
\text { Workshops include icebreaker, presentations, group discussions, and small group activities. }\end{array}$ \\
\hline Mar 2015 & $\begin{array}{l}\text { Workshop I. Evaluations indicate participants would like more FS-rancher interactions, more usable drought information, and } \\
\text { more on-the-ground solutions for dealing with drought. }\end{array}$ \\
\hline \multirow[t]{4}{*}{ Mar-Aug 2015} & $\begin{array}{l}\text { Team provides timely feedback to participants through workshop reports, website, and regular digital and face-to-face } \\
\text { communications with both groups. }\end{array}$ \\
\hline & Develop Standardized Precipitation Index (SPI) information and tools tailored to TNF and user needs. \\
\hline & $\begin{array}{l}\text { Design of codevelopment activities for workshop II takes into account key insights from survey, interviews, and workshop I } \\
\text { evaluations. }\end{array}$ \\
\hline & $\begin{array}{l}\text { Hypothetical ranch and breakout group composition designed to avoid existing tensions or personal attachments. Plan to provide } \\
\text { assistance with computer-based tools. }\end{array}$ \\
\hline July 2015 & Beta test of drought scenario planning tool. \\
\hline Aug 2015 & $\begin{array}{l}\text { Workshop II. Results of scenario planning activity indicate considerable variation in expectation of FS decision process needed to } \\
\text { approve drought preparation practices. }\end{array}$ \\
\hline Aug 2015-Feb 2016 & Design of codevelopment activities for workshop III takes into account workshop II outcomes. \\
\hline Nov 2015 & Discretionary decision discussion with district rangers. \\
\hline Feb 2016 & Workshop III. \\
\hline Mar-May 2016 & Postproject evaluation. \\
\hline
\end{tabular}

more frequent, severe, and longer lasting with climate change (Cayan et al. 2013). Severe drought conditions (<-2 Standardized Precipitation Index, 12 month) have occurred three times since 1895 , most recently in 2002.

The TNF is federal land managed by the FS, which has statutory authority to manage the resources for multiple uses including livestock grazing, recreation, and water quality for downstream users (Rowley 1985). The FS uses a permit system to authorize grazing within designated allotments, and those permits define the number, kind, and class of livestock and timing of use (USDAFS 2016). A permit holder (permittee) must own property to support the ranch headquarters and animal holding facilities. Permittees often refer to base property plus grazing allotment as their "ranch." The permit is accompanied by an allotment management plan (AMP), which provides guidelines for implementing grazing practices. At the beginning of each calendar year, the permittee and FS develop annual operating instructions (AOI) for the upcoming grazing season, which provides for annual flexibility in livestock management in response to resource conditions. Minor deviations from these documents can be approved by the district ranger, however major deviations may require more formal review.

The forest supervisor has decision-making authority for a national forest and a forest-wide range staff coordinates livestock grazing management activities among district staff. District rangers have decision-making authority for discrete ranger districts within a forest and typically have 1-2 range staff who report to them on matters related to managing the livestock permitted to graze on the grazing allotments within the district. On the TNF, there are 6 ranger districts and 100 grazing 
allotments with an average size of 12,000 ha. There are currently five district rangers and four range staff; some share responsibility for more than one district.

About 70 ranchers hold permits to graze cow-calf cattle herds year-round in the TNF. Stocking rates range from 40 to 12 ha $\operatorname{cow}^{-1} \mathrm{y}^{-1}$ along the elevation-precipitation gradient. Calves are the main animal product, and the US\$3 million annual sales and US\$14 million total economic impact account for $80 \%$ of the agricultural economy in Gila County in 2012 (Kerna et al. 2014). Ranchers have relatively small (30-100 ha) base property for operation headquarters. Nearly all are members of the Gila County Cattle Growers Association (GCCGA), which is a chapter of the state-wide Arizona Cattle Growers Association (ACGA) commodity advocacy group.

Livestock grazing on federal lands is also subject to national environmental legislation such as the 1969 National Environmental Policy Act (NEPA) and the 1973 Endangered Species Act (ESA). The NEPA mandates that all executive agencies must analyze the environmental impacts of any proposed action on federal land and that the public should be included in the process. Those proposed actions include the issuing or renewal of grazing permits and many of the practices that can increase preparedness for drought, such as developing more drinking water sources. The level of environmental analysis undertaken is related to the expected level of environmental impact. If the proposed action is expected to have a significant impact, an environmental impact statement (EIS) is used to document the results of a very thorough analysis. If not, an environmental assessment (EA) is used to document the results of a less thorough analysis. Under some circumstances, a categorical exclusion (CE) can be used to further reduce the time it takes to authorize certain types of practices (Sprinkle et al. 2012). The public can provide input to the process in several ways: (1) through an initial scoping process in which the agency solicits comments on the scope of analysis; (2) during public comment periods for the draft and final document; (3) by filing written objections after the document is completed and before a decision has been made; and (4) through an appeal procedure after the decision has been made. Since the 1990s, environmental organizations have used the legal processes made available by environmental legislation such as NEPA and the ESA to influence decisions regarding grazing, which can significantly delay implementation of proposed actions.

District rangers also have administrative discretion about what level of preliminary information gathering and what level of NEPA analysis to pursue for proposed practices. They make those decisions based on many factors, including their comfort with the NEPA process, perception of risk associated with proposed practices, differences in specific circumstances in a project, or preferences of supervisory personnel in the forest or region (MacGregor and Seesholtz 2008, Brown and Squirrel 2010, Jantarasami et al. 2010, Stern et al. 2014).

\section{Participant perspectives}

To better design codevelopment activities, we wanted to understand the diversity of perspectives and potential conflicts among participants. We suspected some animosity between ranchers and the FS because during the recent 2002-2003 drought the FS required all cattle to be removed from the forest (Tronstad and Fuez 2002). To obtain an objective measure of differences in perspective, we performed a systematic assessment of the participants' perspectives through surveys and interviews.

In November 2014, we conducted a mail survey of all grazing permittees $(n=71)$, district rangers $(n=6)$, and range staff $(n=$ $6)$ on the TNF. The dual purposes of the survey were: (1) gain further insight into the views of ranchers and FS on the TNF for the purposes of designing collaborative activities, and; (2) provide a baseline for evaluation of ultimate outcomes of the codevelopment process. Survey questions focused on individuals' views on drought, drought plans, preparation for drought, response practices, drought monitoring and forecasting tools, $\mathrm{U}$. S. Forest Service policy, demographic information, and interest in participating in a codevelopment process. Wording of questions differed slightly on surveys for ranchers and FS employees. The response rate for surveys was 100\% from the FS and 53\% from the ranchers. Ranchers were invited to participate based on stated interest and recommendations from the Gila County Cooperative Extension Director, TNF Range Staff, and GCCGA. All district rangers and range staff from the TNF were directed to attend by the forest supervisor. We conducted in-depth interviews with all FS and rancher invitees, when possible at their ranch or district office. The interviews provided a deeper understanding of participant views and of conflict and trust levels, enriched the team's experiential knowledge of the setting, and helped to build relationships with participants that would enhance their commitment to the project.

In summary, we found tense and contentious relations between the groups and shorter "time in place" (i.e., a composite of the amount of time the interviewee has lived in Arizona, ranched or, worked for the Forest Service on the Tonto National Forest, and/ or been involved in ranching or rangeland management as a FS employee) for FS employees, yet a shared desire to increase interactions between ranchers and FS on the topic of preparing for drought. The ranchers' top three risk factors for managing livestock grazing emphasized poor relations with the FS, whereas risk factors identified by the FS suggest issues with livestock practices performed by ranchers. Ranchers also commented that the rate of turnover in the agency made it difficult to develop and maintain good working relationships with range staff. Importantly, we also learned that the groups shared a view of the most effective practices to address drought, a desire to learn more about preparing for drought, and the belief that the NEPA review process limits management flexibility. We also learned that both groups were unsatisfied with available drought information and wanted information that better characterized local conditions. At Workshop I, which was designed to set the groundwork for codevelopment activities, participants discussed the type of drought information that would be most useful to them. Evaluation of that workshop indicated that participants wanted (in order of decreasing frequency of response): (1) more interactions between ranchers and FS personnel; (2) better information about drought; and (3) more on-the-ground solutions for dealing with drought.

These results highlight several important considerations for designing codevelopment activities for Workshop II. First, given the levels of tension and mistrust between the groups, the codevelopment activities should use hypothetical but realistic, rather than actual examples of grazing, allotments and carefully 
Fig. 2. Codevelopment activities to increase preparation for drought on public rangelands based on collaborative protection motivation theory + health action process approach (C-PMT+HAPA). Note: SPI $=$ Standard Precipitation Index; FS = U.S. Forest Service.

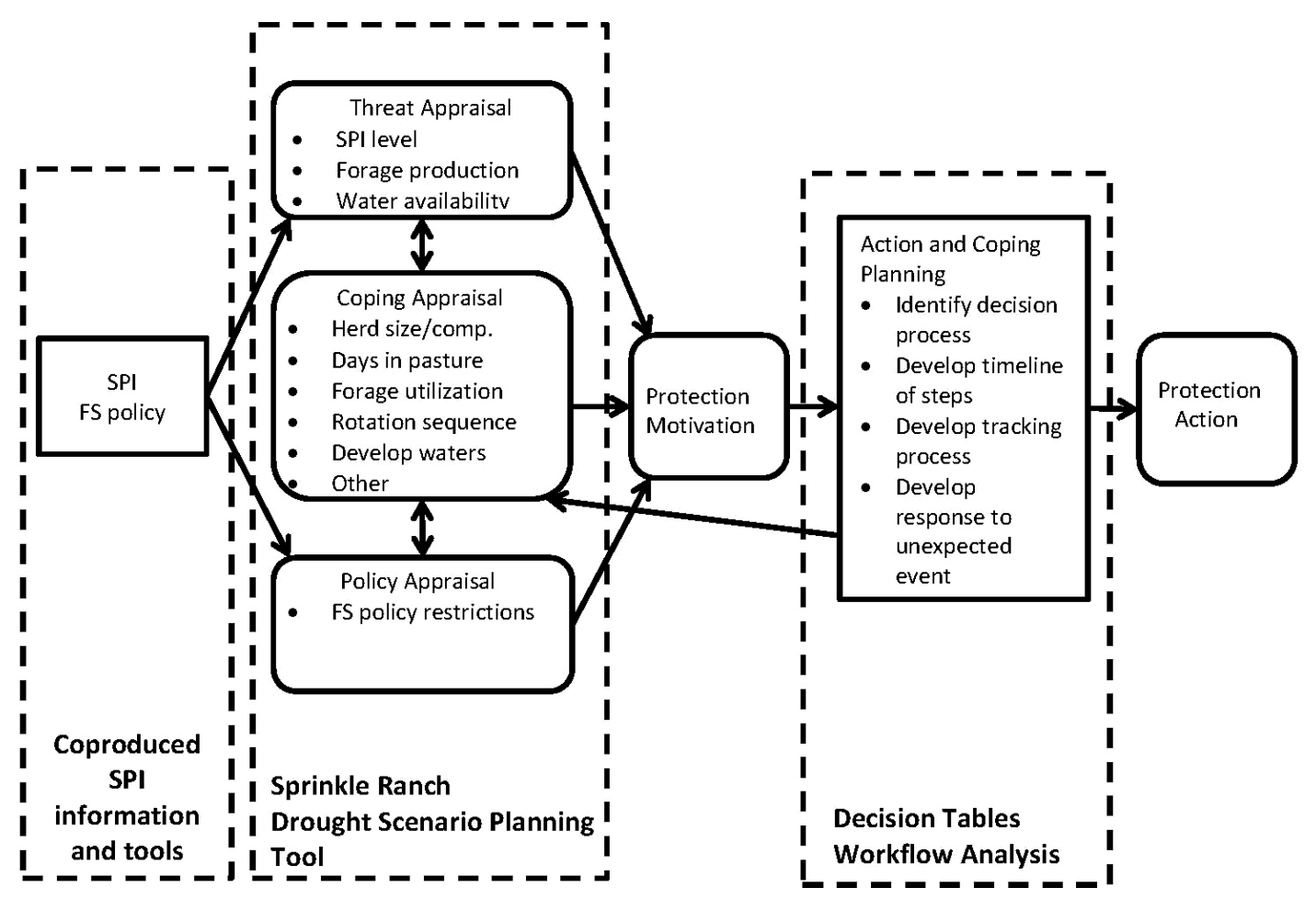

assign membership to working groups to avoid long-standing conflicts. Second, when soliciting coping practices, we should accommodate common as well as nontraditional solutions to provide realism without constraining creativity. Third, we should build on the consistent desire to increase interactions between the groups and to learn more about drought planning by developing realistic decision-making situations during drought to provide an "experiential learning space" in which both parties could share knowledge and learn together (Crimmins et al. 2007, Bartels et al. 2013). Fourth, the activities should provide an opportunity for participants to explore and use drought information together to coproduce with the team drought information that better fit their needs (Lemos and Morehouse 2005).

\section{CODEVELOPMENT ACTIVITIES AND EVALUATION OF INTERMEDIATE OUTCOMES}

Figure 2 shows the codevelopment activities that we applied to enhance drought preparedness based on C-PMT+HAPA and our ongoing evaluation. To reflect the situation of livestock grazing managers on national forests, we added a policy appraisal process. In policy appraisal, individuals consider the impacts of FS policy restrictions on the coping practices available to address a drought threat.

\section{Information sources}

The coproduction process to improve the usability of drought information aimed to improve (1) the fit of drought information with spatial and time scales relevant to livestock managers, (2) the interplay of drought information with the FS decision process, and (3) interaction between information producers and livestock managers. To begin with, having a climatologist on the team improved interaction. Our team climatologist gave presentations and answered questions about drought indices at all workshops and developed and demonstrated web-based drought information tools based on the suggestions and feedback of participants.

To improve interplay, we used the Standardized Precipitation Index (SPI) as a drought indicator because FS Region 3 established a drought policy in 2006 that initiated inspections when SPI (12-month increment) reached -1 (Fig. 2). Using the SPI also improves the fit of drought information because it addresses livestock managers' concerns about the site specificity and prediction accuracy of drought information. The SPI values are expressed in standard deviation units from the historic record mean precipitation for a specific location or region (McKee et al. 1993). Therefore, SPI values for relatively wet locations express the same drought frequency and intensity as in relatively dry locations (Quiring 2009). The likelihood of occurrence of an SPI value also represents the likelihood of occurrence and the return frequency of drought of that intensity. For example, an SPI value of -1 occurs about $16 \%$ of the time in a long-term record $(\sim 1$ in 6 years), and a value of -2 occurs about $2.3 \%$ of the time ( $\sim 1$ in 43 years).

In addition, coproduced information better fit the needs of livestock managers because it characterizes trends in SPI over time, across elevations, between summer and winter seasons, and defines deviations from mean precipitation values for SPI -1 and 
Fig. 3. Drought scenario planning tool and labeled components. Note: SPI = Standard Precipitation Index.

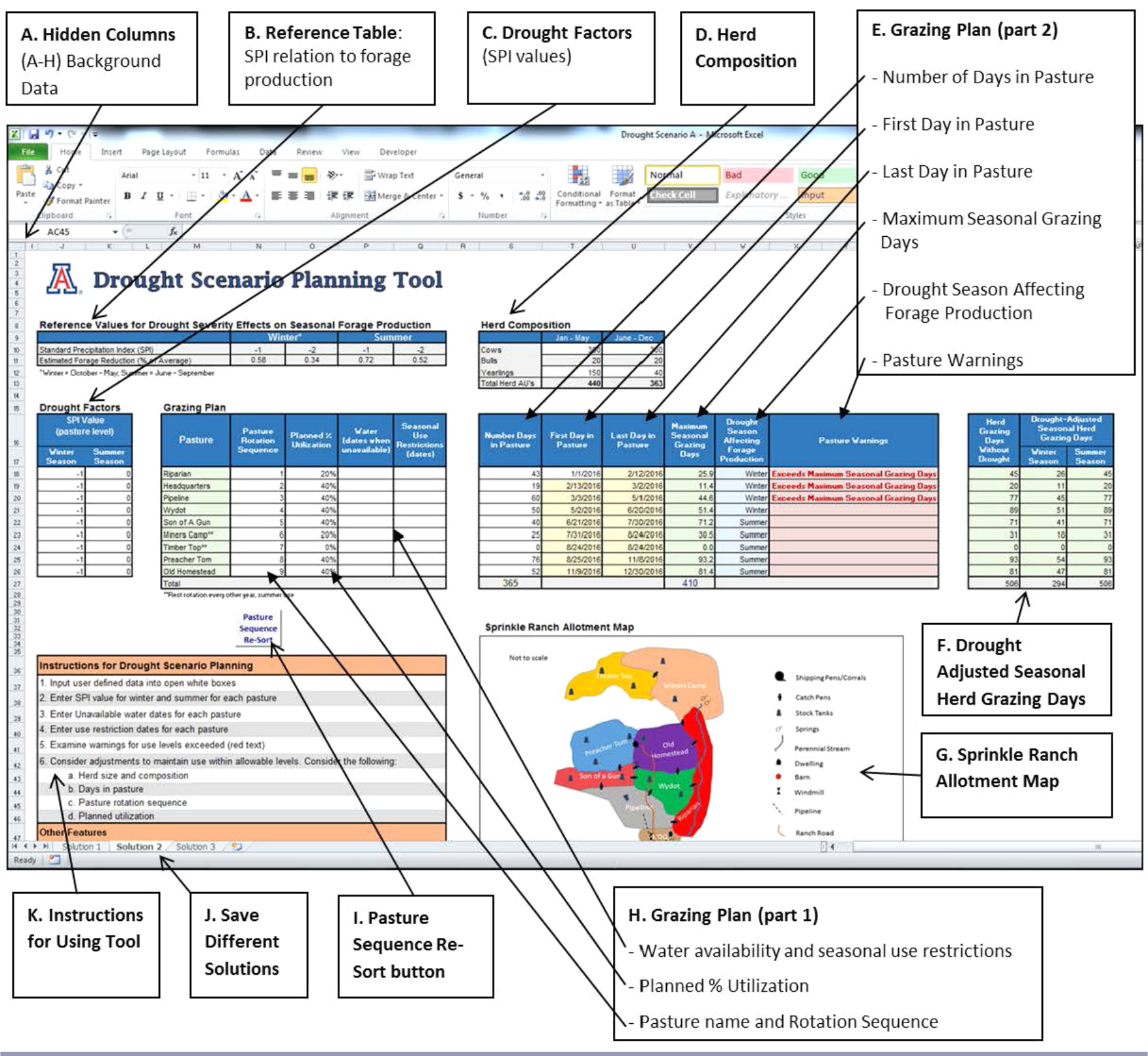

-2 specific to the TNF. The SPI Explorer Tool (https:// uaclimateextension.shinyapps.io/SPItool/) allows users to develop and analyze local-scale estimates of historic precipitation variability.

To coproduce more usable information about the FS decision process, we worked with FS participants to summarize the Region 3 drought policy of SPI -1 , legal requirements for obtaining grazing permits, NEPA review procedures for changes in livestock management and associated infrastructure, and sideboards for discretionary decision making.

Threat and coping appraisals: workshop II

For threat and coping appraisals, the team developed a socialecological model, the drought scenario planning tool (Fig. 3), of a hypothetical, but realistic grazing allotment in the TNF (Sprinkle Ranch, Box G) to support the codevelopment activity in workshop II. We used a hypothetical allotment to avoid tensions or personal attachments related to existing allotments. The tool is an interactive, Microsoft Excel ${ }^{\text {TM}}$-based model that allows users to explore the consequences of preparedness practices (coping appraisal) under different drought intensities (threat appraisal) and FS use restrictions (policy appraisal) on the Sprinkle Ranch. We provide only a brief description of its operation here. The full users' manual can be found on the project website (https://cals.arizona.edu/droughtandgrazing/). We envisioned that small groups composed of ranchers and FS would use the tool to collaboratively develop solutions to a variety of drought and policy scenarios. 
For threat appraisal, the tool uses SPI to represent drought intensity (Box C) and converts SPI to percent of average precipitation for winter and summer seasons in the TNF to create realistic precipitation amounts. To simulate spatial and temporal variability, SPI can be specified for each pasture and for each season. The tool uses data from an ongoing range monitoring program conducted by ranchers and the University of Arizona Cooperative Extension in Gila County to provide realistic forage production numbers for the Sprinkle Ranch, and a simplification of the relationship between percent average precipitation and percent average forage production to represent decreased production during drought. This reduction in forage is captured in the column "Maximum Seasonal Grazing Days" (Box E), which is calculated based on the amount of average forage given for a pasture (Box A), the user-specified seasonal drought conditions (Box C), the user-specified percent allowable forage utilization (Box H), and the user-specified herd composition (Box D). When the user-specified "Number of Days in Pasture" (Box E) exceeds the Maximal Seasonal Grazing Days for that pasture, a warning in red appears in the column "Pasture Warnings" for that pasture. When less than 365 days of total forage is available (sum of Maximum Season Grazing Days column), a warning in red appears below the column. Reductions in available drinking water due to drought are specified in the column titled "Water (dates when unavailable)" (Box H).

For policy appraisal, FS policy constraints are represented in the columns titled "Seasonal Use Restrictions (dates)" and "Planned $\%$ Utilization" (Box H). Initial utilization values reflect typical levels used on the TNF. Seasonal use restrictions are realistic constraints that the FS may place on livestock grazing allotments include restricted use of a pasture during certain dates of the year to avoid conflict with endangered species, high recreation demand, or areas that recently experienced fire, or during the same time of year as the pasture was used the previous year.

For coping appraisal, the tool helps users explore the response to a variety of management decisions to reduce the risk of drought, such as: (1) adjusting herd size and composition (Box D); (2) the number of days the herd can stay in a pasture (Box E); (3) forage utilization in a pasture (Box $\mathrm{H})$; or (4) the order in which the herd rotates through pastures (Box $\mathrm{H}$ ). The goal is to find a combination of practices that will ensure sufficient forage and water for grazing for the year while complying with policy restrictions. There can be many possible solutions and the tool is not capable of representing all of them. For example, if a user wants to develop a new drinking water source, it could either be noted in the water column $(\mathrm{Box} \mathrm{H})$ or recorded on a worksheet that we developed for the purpose of recording solutions (see Appendix 1, Fig. A1.1).

In July 2015, prior to workshop II during which we planned to use the tool, we conducted a beta test with FS personnel and ranchers who were not participating in the codevelopment process. They provided valuable suggestions for improving it, which we incorporated into the final version.

To structure the use of the tool during workshop II, the team developed a set of scenarios. This allowed more time for participants to work together in small groups to find solutions to the scenarios, discuss the FS decision process that would be required to implement them, and share their solutions with the other groups. The scenarios represented plausible combinations of different spatial and seasonal drought conditions and FS use restrictions on the Sprinkle Ranch (see Appendix 1, Table A1.1 for a description of the scenarios). The first three were simple and were performed by the whole group to help them become familiar with the tool and the objectives of the scenario planning exercise. The last two were designed to be performed by smaller groups and to be challenging enough to promote more in-depth discussion, intimate interaction, and strategic thinking between ranchers and FS participants. Four groups were carefully composed by the team to include at least two FS and three ranchers and to avoid pairing district rangers, range staff, and permittees from the same ranger district. We provided each group with a computer, projector, and screen so all members could view the effects of the scenarios as they were applied and the results of solutions as they were being developed. We also provided a computer operator from the research team and a note taker. Two groups each performed the same scenario. Groups developed multiple solutions and recorded scenario solutions and the implementation discussion for each on worksheets we provided (see Appendix 1, Table A1.2 for a summary of solutions). At the conclusion of the small group exercise, each group presented their solutions to the reassembled full group.

Solutions to the scenario planning exercise applied both shortand long-term efforts to address drinking water shortage (hauling water versus permanent pipeline) and changes in pasture rotation and livestock numbers to address shortages in forage production. Solutions included practices that were preparatory, responsive, or both. Preparatory practices are those implemented before the next drought occurs, and may include practices such as implementing a grazing system that promotes forage production, developing permanent water infrastructure, maintaining a conservative or flexible herd size with yearlings, or setting aside pasture reserves (Kachergis et al. 2014). Responsive practices are implemented after the onset of drought has already occurred and may include selling livestock or hauling temporary water (Kachergis et al. 2014, Roche et al. 2015). Solutions also included creative, nonnormative practice such as seeking removal of undesired vegetation, exceptions to policy constraints for grazing use after fire, and a change from cow-calf to yearling livestock composition.

Surprisingly, there was considerable variation among the small groups in the decision types expected to be applied for the same type of coping practice. For example, the level of analysis for a pipeline installation varied from a simple AOI, to a more complex EA, to a very complex EIS. This outcome indicated the need to develop additional activities for workshop III to better simulate action and coping planning. We incorporated the knowledge gained into the codevelopment activity for workshop III.

\section{Action and coping planning: workshop III}

The goal was to allow participants to develop more realistic expectations about the likely type and duration of the decision process for projects to improve preparedness for drought. To coproduce more usable knowledge about the FS decision process to use in the additional activities, we organized a discussion about discretionary decision making with district rangers in November 2015. 
Specifically, in workshop III, the full group first worked together to create a decision table for the FS decision process to approve a proposed water development. It lists characteristics of the project that would affect the likelihood of a particular decision type being used, the most likely FS decision types, and how long the decision process would take to be completed (see Appendix 1, Table A1.3 for the completed table). The resulting table was used during a small group activity in which groups of ranchers and the FS analyzed the workflow for the decision process for a specific water development project and recorded their analysis on a worksheet (see Appendix 1, Fig. A1.2 for an example of a completed worksheet). During this activity, groups performed action planning by identifying: (1) the most likely type of decision given the characteristics of the project; (2) the steps in the decision process; (3) how long it would take to complete the decision process; (4) who would and how to track the progress of the decision process, and; (5) how to communicate that progress. They performed coping planning by identifying: (1) what events might occur to lengthen the process; (2) how much longer the process would take with that event; and; (3) their response to the new event.

Results of these exercises show a general consensus on the expected decision type and the length of the decision process given 14 characteristics of a proposed project (see Appendix 1, Fig. A1.2 for an example of a completed worksheet). When applying those general expectations to two pipeline scenarios, the participants identified a CE decision type lasting 18 months when the scenario included (1) no endangered species, (2) an AMPNEPA scheduled within 3 years, and (3) a 5-year drought plan was in place; and an EA decision type lasting up to 28 months when the scenario included (1) an endangered species, (2) multiple beneficiaries including wildlife interests, and (3) a 5-year drought plan was in place. Expectations for tracking the decision process included involvement by the district ranger, district range staff and the rancher, and possibly the NEPA planner and other beneficiaries of the project. Expected milestones included completed phases of the decision process every 6-12 months, and the scheduling of interactions would be initiated by either/both party/parties to occur at identified milestones or as frequently as monthly. Self-identified new events that could change the process included discovery of new cultural resources, change in FS staffing, and water source for pipeline goes dry; length of delay was $<6$ months; and contingency plans included redesign of project and replacement FS staff.

\section{Evaluation of intermediate outcomes}

At this early stage in the process, we can't expect significant increases in drought preparation or increased resilience of the ecological and human systems to recurring drought. Therefore, we focus on the intermediate social outcomes that are consistent with theories of collaboration and are particularly relevant to addressing improved working relations for groups that do not trust each other. Therefore, our project-specific intermediate outcomes were: (1) improved interactions and relations between ranchers and FS; (2) more usable drought information; (3) improved understanding of drought information and ability to appraise drought risks; (4) improved understanding of practices that increase preparation for drought and the FS process for approving them; (5) increased motivation to implement practices that increase preparation for drought; and (6) the development of plans to implement preparedness practices.
Our social science team member led the evaluation effort, which employed a variety of data collection methods. We used the team's observations of interactions during workshops, results of workshop activities, drought information tool evaluations and postworkshop surveys, and a postproject questionnaire to evaluate intermediate outcomes. For the first data, we digitally recorded all workshops, a team member took notes during each, and the team discussed their observations of interactions at the team meeting after each workshop. We assigned note-takers to each group during the small group activities and saved all worksheets from the activities. Participants completed a postworkshop evaluation at the end of each workshop and a postproject evaluation by email. The surveys included Likertscale and open-response questions and did not distinguish between rancher and FS respondents. The four Likert-scale categories range from strongest to weakest support for a statement: greatly (great), moderately (mod), minimally (min), and not at all (none). The postproject evaluation consisted of five open-ended questions. Return rates on the workshop evaluations were 19 of 29 rancher and FS participants for workshop I, 28 of 30 for workshop II, 24 of 27 for workshop III, and 23 of 29 for the postproject evaluation.

Evaluation of intermediate outcomes indicates: (1) improved interactions and relations between ranchers and FS; (2) improved understanding of drought information and ability to appraise drought risks; (3) improved understanding of practices that increase preparation for drought and of the FS process for approving them, and; (4) increased motivation to implement practices that increase preparation for drought (Table 2). Survey responses indicated improved interactions and relations $(65-71 \%$ greatly), and team member observations during the workshops are consistent with that survey result. Several respondents described the improvement in terms of developing a common language in which to talk about drought. According to note-taker observers, one event in workshop II may have been critical to improve interactions. Tensions were high until a district ranger spoke up to express that the Forest Service "doesn't like the red tape caused by NEPA [for approving practices] either; the law is restricting and they want to move things forward with NEPA as quickly as the ranchers do." This district ranger also expressed that there is personal liability involved in making decisions that may conflict with the law, including losing their job and possibly even their house if a lawsuit was filed. Some ranchers responded with comments about not realizing the type of personal risk that district rangers can face.

Ninety-seven percent of responses reported improved $(43 \%$ greatly) understanding of SPI as an indicator of drought frequency and threat (Table 2). The team also observed that participants began to use the term "SPI" knowledgeably in discussion during workshop activities. Improved understanding of practices was reported by $89-92 \%$ of respondents, but many wanted more information. Understanding of the FS decision process improved after workshop III to $91 \%$ (35\% greatly) from $71-75 \%$ (21-25\% greatly) after workshop II when $85 \%$ of written comments asked for more information.

Postproject evaluations suggest an emerging level of motivation to increase preparation and to do so collaboratively. Responding to "What is the first thing you are going to do and when?" 6 of 14 responding ranchers would develop a drought plan and half 
Table 2. Results of workshop evaluations (only two undecided in interactions for workshop III). The four Likert-scale categories range from strongest to weakest support for a statement: greatly (great), moderately (mod), minimally (min), and not at all (none).

\begin{tabular}{lll}
\hline & \multicolumn{2}{c}{ Response Categories (\%) } \\
\cline { 2 - 3 } Question & Great Mod Min None & Open Responses (number and examples) \\
\hline
\end{tabular}

Interactions

How well did the workshop facilitate constructive interaction between ranchers and Forest Service? (Workshop II, N = 28)

How well did the workshop facilitate constructive interaction between ranchers and Forest Service? (Workshop III, N = 23, 9\% undecided)

Drought information and risk appraisal How well did the workshop activities improve your understanding of how drought information could be used to increase your ability to prepare for drought? (Workshop II, $\mathrm{N}=28$ )

Practices for drought preparation

How well did the workshop improve your knowledge of practices to increase planning for drought on the Tonto National Forest? (Workshop II, N = 28)

How well did the workshop improve your knowledge of practices to consider for long-term drought planning on the Tonto NF? (Workshop III, $\mathrm{N}=23$ )

FS decision process

How well did the workshop improve your understanding of how Forest Service policies and decision processes can constrain or facilitate flexibility in grazing management? Workshop II, $\mathrm{N}=28)$

How well did the workshop activities improve your understanding of how district rangers can use their discretion when making decisions about livestock management in their district?

(Workshop II, $\mathrm{N}=28$ )

How well did the workshop improve your understanding of how to become engaged in Forest Service decision processes for long-term planning on the Tonto NF? (Workshop III, N = 23)
10 positive, 2 want more next workshop

POSITIVE: Good discussion on the fact that droughts occur every 1 of 6 years $(-1$ SPI).

Getting better understanding of SPI [was the most valuable part of the workshop].

WANT MORE: More info about applying SPI to local changes [should be a part of the next workshop].

4

5 positive, 3 want more next workshop

POSITIVE: Model forced us all to think of solutions to the drought.

WANT MORE: [Want more] Things ranchers and Forest Service can do on-the-ground/cow \#'s, preparation of drought, because it is coming.

$\begin{array}{lllll}57 & 35 & 4 & 4 & 1 \text { comment }\end{array}$

Realistic expectation of the time line involved.

14 positive, 12 not improved and want more next workshop POSITIVE: The personnel explained their positions and what we can do to expedite our projects.

I have a better idea of what agencies will be looking for to make decisions.

WANT MORE: A better discussion on what is required in the way of Forest Service decision documentation and what are realistic time frames for clearances or decision documents [should be included in the next workshop].

9 positive, but not pleased

Each ranger has great latitude in how helshe interprets Forest Service policy. Therefore, what the ranger said in my group may not be the same in the other groups today.

This is always an important point to make clear to everyone: expectations do not always match reality.

$\begin{array}{lllll}35 & 61 & 0 & 4 & 6 \text { comments }\end{array}$

Made me have a greater realization of the importance of involvement in the process. I need to be involved more in FS planning, not just for drought.

Ranchers and FS working together to gain a mutual understanding of the timeliness and expectations. 
of those together with the FS, and 3 would pursue water development (only 1 together with the FS). Two ranchers said they have always done drought planning, and one said not much would change. Of the nine FS responses, five would use the planning tools developed in the workshops to engage ranchers, one would start a workshop process at their new work location, and one would discuss internally with FS employees. One rancher wrote: "I plan to sit down with my range-con (FS) and develop a drought preparedness plan," and one FS wrote: "I am already speaking with permittees (ranchers) to plan this year's rotation ... Laying foundation for the 'drought talk' early in the year will help if those discussions need to become more serious later."

Including drought preparedness as a regular part of AOI meetings was suggested by half of the respondents ( 5 of 9 ranchers and 2 of 4 FS) to the question, "How could long-term drought planning become a regular part of the management conversation between ranchers and Forest Service?" One rancher wrote: “... drought planning should be a requirement of all AOI discussions. The planning should not be the rancher's sole responsibility but the FS as well." Others supported frequency conversations about drought planning (4 of 9 ranchers and 2 of 4 FS), and one FS response suggested: "We want to start a quarterly workshop that moves around the forest for FS, ranchers, University, Game and Fish, etc. ... [as] a venue to continue conversations."

\section{DISCUSSION}

\section{C-PMT+HAPA framework}

The strengths of the intermediate outcomes suggest that C-PMT+ HAPA would be an effective, theoretically supported framework for designing and evaluating codevelopment processes that encourage preparation for natural hazards in situations in which decisions are shared and actions must be taken jointly by more than one party. The framework provides specific guidance for designing and structuring the actual activities in which collaborators will participate, when such guidance is lacking (Conley and Moote 2003, von Korff et al. 2010, 2012). It also suggests intermediate outcomes that indicate progress toward improved preparedness: (1) improved interactions and relations between the parties; (2) more usable information about the natural hazard; (3) improved risk assessment; (4) improved ability to develop practices to increase preparation; (5) increased motivation to implement these practices; and (6) the development of plans to implement these practices. These intermediate outcomes are consistent with the principles of building resilience in social-ecological systems by fostering systems thinking, encouraging learning, and broadening participation (Biggs et al. 2015, Folke 2016, Stern and Baird 2015). Therefore, we expect that even if few preparedness actions are implemented in the near term, there has been an increase in the resilience of this public rangelands social-ecological system to resist and recover from future droughts and other shocks to the system. We encourage others to consider this approach for increasing preparedness for other natural hazards and to suggest improvements.

Each application of the C-PMT+HAPA framework will have its own context-based guiding considerations. We chose to simulate preparedness planning with the goal of participants applying that skill to develop actual drought preparation plans, but the framework could also be used to develop actual practices and plans for increasing preparedness in real natural hazards planning situations. We chose to develop the social-ecological model and the scenarios because of time constraints and because there was already considerable agreement between ranchers and FS about how public rangeland systems work. But they could be codeveloped by participants in situations in which a goal is to develop agreement about critical uncertainties.

The application of C-PMT+HAPA is not simple: it requires significant project-specific preliminary research, ongoing evaluation, and long duration to develop the supporting tools for codevelopment activities and to iteratively redesign activities that are not effective. In our case, this process was significantly assisted by the wide range of expertise on the project team and the substantial social capital among ranchers and FS built by the Gila County Extension Director who was a member of the team. We can envision a faster application than 1.5 years, especially if the lessons learned from this effort provide the basis for a more rapid program of coproducing usable information, developing socialecological models and relevant scenarios, and action and coping planning activities to apply the solutions to the scenarios. However, rushing through the process may not have allowed us to make the very critical midcourse correction in the action and coping planning activities between workshops II and III. The tension between expediency and iterativity is a challenge in collaborative processes and in the development of usable information (Lemos and Morehouse 2005, Dilling and Lemos 2011). Our advice is to not assume that collaboration, and specifically C-PMT-HAPA, is a "one and done" activity; rather it will require significant time investment to ensure that the participants can absorb the input and can adequately express their preferences and needs, and the facilitators can change course when needed.

We suggest several explanations for the effectiveness of the CPMT+HAPA framework. First, several of the theories and methods used to operationalize it, including coproduction of usable knowledge, social-ecological modeling, and scenario planning, each have the potential outcomes of improved communication, relationships, and trust (Wollenberg et al. 2000, Lemos and Morehouse 2005, Stern and Baird 2015, Price et al. 2016). Our results indicate that, of the expected intermediate outcomes, the codevelopment activities were most successful in improving interactions and relations between the parties. This suggests that in combination, these approaches help to realize and reinforce the relationship building potential of each other.

Second, collaborative processes, social-ecological modeling, and scenario planning are each expected to improve decision making in situations of high uncertainty and complexity (von Korff et al. 2010, Addison et al. 2013, Amer et al. 2013, Rowland et al. 2014, Reyers et al. 2015, Price et al. 2016). For example, coproduced information and codeveloped protective practices are more likely to be seen as credible (technically and practically sound), salient (relevant to participants' needs), and legitimate (created by a fair process) by participants (Cash et al. 2003, Lemos and Morehouse 2005) and therefore more likely to be used, than information and practices handed down by experts, as in PMT+HAPA. In CPMT+HAPA, participants collaboratively appraise the risk of a natural hazard and codevelop preparedness practices and plans to implement those practices. 
Third, the codevelopment activities we designed target both the analytical and experiential components of learning (Kolb 1984). We coproduced more usable drought information and information about the FS decision process, and the codevelopment activities provided the opportunity for participants to practice using it in realistic drought situations. Research suggests that participation processes that incorporate experiential learning through local, context-specific and interactive engagement allow participants to better understand and interpret analytic information and integrate it into current experiences for better outcomes (Eriksen and Prior 2011, Bartels et al. 2013). The experience of practicing working together in realistic drought situations under less stress than in an actual drought both improved relationships and provided learning to draw on in an actual drought.

Several collaborative processes to address natural hazards preparation or climate change adaptation have employed a framework similar to C-PMT+HAPA, but without its theoretical underpinning. For example, the Adaptation for Conservation Targets (ACT) framework for natural resource planning in light of climate change uses social-ecological modeling and scenario planning to motivate collaborative, scientifically defensible planning and decision making for specific landscapes by a multidisciplinary group of practitioners (Cross et al. 2012, 2013). Exit surveys indicated that participants in workshops based on the ACT framework reported improved understanding of climate change and its local effects and of how to develop adaptation strategies and incorporate them into their conservation work. However, without a theoretical basis, it cannot be assumed that these intermediate outcomes will increase the likelihood of implementing workshop recommendations. In addition, without the inclusion of action and coping planning in the process, the ACT framework was unable to address institutional and regulatory constraints that circumscribe implementation.

\section{Challenges for increasing preparation for drought on federal rangelands}

Flexibility in the form of multiple options for response to drought conditions was valued by both the ranchers and public land managers among the participants. In this regard, they subscribe to the same "increase flexibility" paradigm as private land ranchers (Coppock 2011, Knutson and Haigh 2013, Kachergis et al. 2014, Derner and Augustine 2016). However, our participants recognized that the review/approval processes for public lands is a significant barrier to the attainment of the optimal level of flexibility for drought or any other expected, but unpredictable, natural hazard.

Given our participants' increased motivation to become better prepared for drought, we see some reason for optimism regarding the value of proactively developing increased flexibility to respond to drought conditions on public rangelands using the codevelopment process based on the C-PMT+HAPA framework. However, we remain concerned that these intentions exist only as ad hoc behaviors that are subject to the ephemeral composition of district rangers and range staff. For example, during our 1.5 year project, there was a $60 \%$ turnover in district rangers and a $40 \%$ turnover in range staff, which is especially critical given the importance of their discretionary authority in approving projects that are intended to increase flexibility (MacGregor and Seesholtz
2008, Brown and Squirrel 2010, Jantarasami et al. 2010, Stern et al. 2014). Therefore, we see great value in formalizing and institutionalizing the collaborative development of drought flexibility plans so that the best shared intentions have the prospect of persisting through the inevitable change in personnel. To that end, we produced a Guide to Co-Developing Drought Preparation Plans for Livestock Grazing on the Southwest National Forests (Hawkes et al. 2018), which applies the C-PMT+HAPA structure for engaging ranchers and FS staff through a series of worksheets.

Another challenge involves the fit of drought information. Our very positive intermediate outcomes reflect the expected benefits of developing drought information tools that fit the context and needs of participants (Lemos et al. 2012). For example, although SPI is retrospective and cannot be used to predict drought occurrence, project participants found estimates of return frequency and historic precipitation variability extremely valuable for drought planning. The retrospective information was a good fit because it helped interpret the current FS drought policy and subsequently develop realistic plans for achieving collaborative solutions.

This retrospective drought information is very different from the seasonal forecasts of drought conditions that are framed as "drought early warning" tools (Wilhite et al. 2014). The fit is more difficult for seasonal forecasts because in public land settings there is currently not enough flexibility available for ranchers and land managers to respond to those warnings. During the codevelopment process, we learned that it can take three to four years for the required NEPA review/approval process to be completed for the basic practices and infrastructure needed to increase flexibility. In short, the provision of seasonal forecast information does not fit those public land situations until those flexibility practices have been approved and put in place (Lemos et al. 2012). Therefore, we suggest that there be more coordinated effort between developing better forecasts with a tandem effort to increase the capacity of users to apply those seasonal forecasts. In our case, this translates to assisting public land ranchers and land managers to complete the needed assessments, drought preparation plans, and approvals so that these seasonal forecasts can be more actionable and a better fit for these situations.

In conclusion, the C-PMT+HAPA provides much needed guidance for designing, implementing, and evaluating the specific activities for a codevelopment process to increase preparation for natural hazards in situations in which protective actions must be taken jointly by more than one party (von Korff et al. 2010, Reed et al. 2014, Talley et al. 2016). It also contributes a concrete method for realizing a paradigm shift in disaster science (IsmailZadeh et al. 2017). The substantial time commitment demanded is justified by the great promise codevelopment approaches based on C-PMT+HAPA show for improving preparation for natural hazards.

Responses to this article can be read online at: http://www.ecologyandsociety.org/issues/responses. php/10503 


\section{Acknowledgments:}

We thank the ranchers and Forest Service employees who participated in our project for their dedication and invaluable feedback. We thank Tonya Haigh from the National Drought Mitigation Center, and our other Team members, Michael A. Crimmins, Larry D. Howery, George B. Ruyle, James E. Sprinkle, and Douglas R. Tolleson for their outstanding interdisciplinary collaboration. This work was supported by the National Oceanic and Atmospheric Administration's Climate Program Office through Award NA14OAR4310242.

\section{LITERATURE CITED}

Addison, P. F. E., L. Rumpff, S. S. Bau, J. M. Carey, Y. E. Chee, F. C. Jarrad, M. F. McBride, and M. A. Burgman. 2013. Practical solutions for making models indispensable in conservation decision-making. Diversity and Distributions 19:490-502. http:// dx.doi.org/10.1111/ddi.12054

Amer, M., T. U. Daim, and A. Jetter. 2013. A review of scenario planning. Futures 46:23-40. Futures 46:23-40. http://dx.doi. org/10.1016/j.futures.2012.10.003

Ansell, C., and A. Gash. 2008. Collaborative governance in theory and practice. Journal of Public Administration Research and Theory 18(4):543-571. http://dx.doi.org/10.1093/jopart/mum032

Bartels, W.-L., C. A. Furman, D. C. Diehl, F. S. Royce, D. R. Dourte, B. V. Ortiz, D. F. Zierden, T. A. Irani, C. W. Fraisse, and J. W. Jones. 2013. Warming up to climate change: a participatory approach to engaging with agricultural stakeholders in the Southeast US. Regional Environmental Change 13(Suppl 1):45-55. http://dx.doi.org/10.1007/s10113-012-0371-9

Biggs, R., M. Schlüter, and M. L. Schoon. 2015. Principles for building resilience: sustaining ecosystem services in socialecological systems. Cambridge University Press, Cambridge, UK. http://dx.doi.org/10.1017/CBO9781316014240

Briske, D. D., L. A. Joyce, H. W. Polley, J. R. Brown, K. Wolter, J. A. Morgan, B. A. McCarl, and D. W. Bailey. 2015 Climatechange adaptation on rangelands: linking regional exposure with diverse adaptive capacity. Frontiers in Ecology and the Environment 13(5):249-256. http://dx.doi.org/10.1890/140266

Brown, G. G., and T. Squirrel. 2010. Organizational learning and the fate of adaptive management in the US Forest Service. Journal of Forestry 108:379-388.

Cash, D. W., W. C. Clark, F. Alcock, N. M. Dickson, N. Eckley, D. H. Guston, J. Jäger, and R. B. Mitchell. 2003. Knowledge systems for sustainable development. Proceedings of the National Academy of Sciences 100(14):8086-8091. http://dx.doi.org/10.1073/ pnas. 1231332100

Cayan, D. R., M. Tyree, K. E. Kunkel, C. Castro., A. Gershunov, J. Barsugli, A. J. Ray, J. Overpeck, M. Anderson, J. Russell, B. Rajaopalan, I. Rangwala, P. Duffy, and M. Barlow. 2013. Future climate: projected average. Pages 101-125 in G. Garfin, A. Jardine, R. Merideth, M. Black, and S. LeRoy, editors. Assessment of climate change in the Southwest United States: a report prepared for the national climate assessment. Island, Washington, D.C., USA. http://dx.doi.org/10.5822/978-1-61091-484-0_6
Conley, A., and M. M. Moote. 2001. Collaborative conservation in theory and practice: a literature review. Udall Center for Studies in Public Policy, University of Arizona, Tucson, Arizona, USA. [online] URL: http://udallcenter.arizona.edu/publications/epp/ pdfs/2001 conley.moote collaborative.conservation.pdf

Conley, A., and M. M. Moote. 2003. Evaluating collaborative natural resource management. Society and Natural Resources 16 (5):371-386. http://dx.doi.org/10.1080/08941920309181

Coppock, D. L. 2011. Ranching and multiyear drought in Utah: production impacts, risk perceptions, and changes in preparedness. Rangeland Ecology and Management 64:607-618. http://dx.doi.org/10.2111/REM-D-10-00113.1

Crimmins, M. A., G. Zaimes, N. Haas, C. Jones, G. Garfin, and T. Crimmins. 2007. Changes on the range: a novel exercise to explore interactions between range management decision making and climate change. Journal of Natural Resources and Life Sciences Education. 36:76-86.

Crimmins, M. A., and M. P. McClaran. 2016. Where do seasonal climate predictions belong in the drought management toolbox? Rangelands 38(4):169-176. http://dx.doi.org/10.1016/j.rala.2016.06.004

Cross, M. S., P. D. McCarthy, G. Garfin, D. Gori, and C. A. F. Enquist. 2013. Accelerating adaptation of natural resource management to address climate change. Conservation Biology 27 (1):4-13. http://dx.doi.org/10.1111/j.1523-1739.2012.01954.x

Cross, M. S., E. S. Zavaleta, D. Bachelet, M. L. Brooks, C. A. F. Enquist, E. Fleishman, L. J. Graumlich, C. R. Groves, L. Hannah, L. Hansen, G. Hayward, M. Koopman, J. J. Lawler, J. Malcolm, J. Nordgren, B. Petersen, E. L. Rowland, D. Scott, S. L. Shafer, M. R. Shaw, and G. M. Tabor. 2012. The adaptation for conservation targets (ACT) framework: a tool for incorporating climate change into natural resource management. Environmental Management 50(3):341-351 http://dx.doi.org/10.1007/s00267-012-9893-7

Derner, J. D., and D. J. Augustine. 2016. Adaptive management for drought on rangelands. Rangelands 38(4):211-215. http://dx. doi.org/10.1016/j.rala.2016.05.002

Dilling, L., and M. C. Lemos. 2011. Creating usable science: opportunities and constraints for climate knowledge use and their implications for science policy. Global Environmental Change 21:680-689. http://dx.doi.org/10.1016/j.gloenvcha.2010.11.006

Eriksen, C., and T. Prior. 2011. The art of learning: wildfire, amenity migration and local environmental knowledge. International Journal of Wildland Fire 20:612-624. http://dx.doi. org/10.1071/WF10018

Floyd, D. L., S. Prentice-Dunn, and R. W. Rogers. 2000. A metaanalysis of research on the protection motivation theory. Journal of Applied Social Psychology 30(2):407-429. http://dx.doi. org/10.1111/j.1559-1816.2000.tb02323.x

Folke, C. 2016. Resilience (Republished). Ecology and Society 21 (4):44. http://dx.doi.org/10.5751/ES-09088-210444

Funtowivz, S. O., and J. R. Ravetz. 1993. Science for the postnormal age. Futures 25(7):739-755. http://dx.doi.org/10.1016/0016-3287 (93)90022-L

Gaston, A., and H. Prapavessis. 2014. Using a combined protection motivation theory and health action process approach 
intervention to promote exercise during pregnancy. Journal of Behavioral Medicine 37(2):173-184. http://dx.doi.org/10.1007/ $\underline{\mathrm{s} 10865-012-9477-2}$

Georgakopoulos, D., M. Hornick, and A. Sheth. 1995. An overview of workflow management: from process modeling to workflow automation infrastructure. Distributed and Parallel Databases 3:119-153. http://dx.doi.org/10.1007/BF01277643

Grothmann, T., and A. Patt. 2005. Adaptive capacity and human cognition: the process of individual adaptation to climate change. Global Environmental Change 15:199-213. http://dx.doi. org/10.1016/j.gloenvcha.2005.01.002

Grothmann, T., and F. Reusswig. 2006. People at risk of flooding: why some residents take precautionary action while others do not. Natural Hazards 38:101-120. http://dx.doi.org/10.1007/s11069-005-8604-6

Havstad, K. M., D. Peters, B. Allen-Diaz, B. Bestelmeyer, D. Briske, J. R. Brown, M. Brunson, J. E. Herrick, P. Johnson, L. Joyce, R. Pieper, A. J. Svejcar. J. Yao, J. Bartolome, and L. Huntsinger. 2009. The Western United States rangelands, a major resource. Pages 75-93 in W. F. Wedin and S. L. Fales, editors. Grassland, quietness and strength for a new American agriculture. America Society of Agronomy, Crop Science Society of America, and Soil Science Society of America, Madison, Wisconsin, USA. http://dx.doi.org/10.2134/2009.grassland.c5

Hawkes, K. L., M. P. McClaran, J. Brugger, M. A. Crimmins, L. D. Howery, G. B. Ruyle, J. E. Sprinkle, and D. R. Tolleson. 2018. Guide to co-developing drought preparation plans for livestock grazing on the southwest national forests. Cooperative Extension Bulletin az1764. University of Arizona Cooperative Extension, Tucson, Arizona, USA. [online] URL: https://extension.arizona. edu/sites/extension.arizona.edu/files/pubs/az1764-2018.pdf

Ismail-Zadeh, A. T., S. L. Cutter, K. Takeuchi, and D. Paton. 2017. Forging a paradigm shift in disaster science. Natural Hazards 86:969-988. http://dx.doi.org/10.1007/s11069-016-2726$\underline{x}$

Jantarasami, L. C., J. J. Lawler, and C. W. Thomas. 2010. Institutional barriers to climate change adaptation in the US national parks and forests. Ecology and Society 15(4):3. http://dx. doi.org/10.5751/ES-03715-150433

Kachergis, E., J. D. Derner, B. B. Cutts, L. M. Roche, V. T. Eviner, M. N. Lubell, and K. W. Tate. 2014. Increasing flexibility in rangeland management during drought. Ecosphere 5(6):1-14. http://dx.doi.org/10.1890/ES13-00402.1

Kelley, W. K., J. D. Scasta, and J. D. Derner. 2016. Advancing knowledge for proactive drought planning and advancing adaptive management for drought on rangelands: introduction to a special issue. Rangelands 38(4):159-161. http://dx.doi. org/10.1016/j.rala.2016.06.008

Kerna, A., G. Frisvold, R. Tronstad, and T. Teegerstrom. 2014. The contribution of the beef industry to the Arizona economy. Department of Agricultural and Resource Economics, University of Arizona, Tucson, Arizona, USA. [online] URL: https://cals. arizona.edu/arec/sites/cals.arizona.edu.arec/files/publications/ contrib_beef_industry to_az_econ_complete.pdf
Kirk, H. W. 1964. Use of decision tables in computer programming. Communications of the ACM 8(1):41-43. http://dx. doi.org/10.1145/363707.363725

Koerth, J., A. T. Vafeidis, J. Hinkel, and H. Sterr. 2013. What motivates coastal households to adapt pro-actively to sea-level rise and increasing flood risk? Regional Environmental Change 13:897-909. http://dx.doi.org/10.1007/s10113-012-0399-x

Kolb, D. A. 1984. Experiential learning: experience as the source of learning and development. Prentice-Hall, Upper Saddle River, New Jersey, USA.

Knapp, C. N., M. Fernandez-Gimenez, E. Kachergis, and A. Rudeen. 2011. Using participatory workshops to integrate stateand-transition models created with local knowledge and ecological data. Rangeland Ecology and Management 64 (2):158-170. http://dx.doi.org/10.2111/REM-D-10-00047.1

Knutson, C., and T. Haigh. 2013. A drought-planning methodology for ranchers in the Great Plains. Rangelands 35 (1):27-33. http://dx.doi.org/10.2111/RANGELANDS-D-12-00075.1

LaChappelle, P. R., S. F. McCool, and M. E. Patterson. 2003. Barriers to effective natural resource planning in a "messy" world. Society and Natural Resources 16:473-490. http://dx.doi. org/10.1080/08941920309151

Lemos, M. C., C. J. Kirchhoff, and V. Rampradsad. 2012. Narrowing the climate information usability gap. Nature Climate Change 2:789-794. http://dx.doi.org/10.1038/nclimate1614

Lemos, M. C., and B. J. Morehouse. 2005. The co-production of science and policy in integrated climate assessments. Global Environmental Change 15:57-68. http://dx.doi.org/10.1016/j. gloenvcha.2004.09.004

MacGregor, D. G., and D. N. Seesholtz. 2008. Factors influencing line officers' decisions about National Environmental Policy Act project design and development. USDA Forest Service General Technical Report PNW-GTR-766. USDA Forest Service, Portland, Oregon, USA. http://dx.doi.org/10.2737/PNW$\underline{\text { GTR-766 }}$

Macon, D. K., S. Barry, T. Bechetti, J. S. Davy, M. P. Duran, J. A. Finzel, H. George, J. M. Harper, L. Huntsinger, R. S. Ingram, D. E. Lancaster, R. E. Larsen, D. J. Lewis, D. F. Lile, N. K. McDougald, F. E. Mashiri, G. Nader, S. R. Oneto, J. W. Stackhouse, and L. M. Roche. 2016. Coping with drought on California rangelands. Rangelands 38(4):222-228. http://dx.doi. org/10.1016/j.rala.2016.06.005

Martin, I. M., H. Bender, and C. Raish. 2007. What motivates individuals to protect themselves from risks: the case of wildland fires. Risk Analysis 27(4):887-900. http://dx.doi.org/10.1111/ j.1539-6924.2007.00930.X

McClaran, M. P., G. J. Butler, H. Wei, and G. D. Ruyle. 2015. Increased preparation for drought among livestock producers reliant on rain-fed forage. Natural Hazards 79:151-170. http://dx. doi.org/10.1007/s11069-015-1834-3

McClaran, M. P., and H. Wei. 2014. Recent drought phase in a 73-year record at two spatial scales: implications for livestock production on rangelands in the Southwestern United States. 
Agriculture and Forest Meteorology 197:40-51. http://dx.doi. org/10.1016/j.agrformet.2014.06.004

McKee, T. B., N. J. Doesken, and J. Kleist. 1993. The relationship of drought frequency and duration to time scales. In Eighth conference on applied climatology 17-22 January 1993, Anaheim, California. American Meteorological Society, Boston, Massachusetts, USA. [online] URL: http://www.droughtmanagement.info/ literature/AMS Relationship Drought Frequency Duration Time Scales 1993.pdf

Meadow, A. M., D. B. Ferguson, Z. Guido, A. Horangic, G. Owen, and T. Wall. 2015. Moving toward the deliberate coproduction of climate science knowledge. Weather, Climate, and Society 7(2):179-191. http://dx.doi.org/10.1175/WCASD-14-00050.1

Patton, M. Q. 2010. Developmental evaluation: applying complexity concepts to enhance innovation and use. Guilford, New York, New York, USA.

Price, J. M., J. Silbernagel, K. Nixon, A. Swearingen, R. Swaty, and N. Miller. 2016. Collaborative scenario modeling reveals potential advantages of blending strategies to achieve conservation goals in a working forest landscape. Landscape Ecology 31:1093-1115. http://dx.doi.org/10.1007/s10980-015-0321-2

Quiring, S. M. 2009. Monitoring drought: an evaluation of meteorological drought indices. Geography Compass 3(1):64-88. https://doi.org/10.1111/j.1749-8198.2008.00207.x

Reed, M. S., L. C. Stringer, I. Fazey, A. C. Evely, and J. H. J. Kruijsen. 2014. Five principles for the practice of knowledge exchange in environmental management. Journal of Environmental Management 146:337-345. http://dx.doi.org/10.1016/j. jenvman.2014.07.021

Reid, R. S., M. E. Fernández-Giménez, and K. A. Galvin. 2014. Dynamics and resilience of rangelands and pastoral peoples around the globe. Annual Review of Environment and Resources 39:217-242. http://dx.doi.org/10.1146/annurev-environ-020713-163329

Reyers, B., J. L. Nel, P. J. O'Farrell, N. Sitas, and D. C. Nel. 2015. Navigating complexity through knowledge coproduction: mainstreaming ecosystem service into disaster risk reduction. Proceedings of the National Academy of Sciences 112 (24):7362-7368. http://dx.doi.org/10.1073/pnas.1414374112

Robertson, D. P., and R. B. Hull. 2003. Public ecology: an environmental science and policy for global society. Environmental Science and Policy 6:399-410. http://dx.doi. org/10.1016/S1462-9011(03)00077-7

Roche, L. M., T. K. Schohr, J. D. Derner, M. N. Lubell, B. B. Cutts, E. Kachergis, V. T. Eviner, and K. W. Tate. 2015. Sustaining working rangelands: insights from rancher decision making. Rangeland Ecology and Management 68(5):383-389. http://dx.doi. org/10.1016/j.rama.2015.07.006

Rogers, R. W. 1975. A protection motivation theory of fear appeals and attitude change. Journal of Psychology 91:93-114. http://dx.doi.org/10.1080/00223980.1975.9915803

Rowland, E. L., M. S. Cross, and H. Hartman. 2014. Considering multiple futures: scenario planning to address uncertainty in natural resource conservation. U.S. Fish and Wildlife Service, Washington
D.C., USA. [online] URL: https://www.fws.gov/home/climatechange/ pdf/Scenario-Planning-Report.pdf

Rowley, W. D. 1985. U.S. Forest Service grazing and rangelands: a history. Texas A\&M University Press, College Station, Texas, USA.

Sayre, N. F., R. R. J. McAllister, B. T. Bestelmeyer, M. Moritz, and M. D. Turner. 2013. Earth stewardship of rangelands: coping with ecological, economic, and political marginality. Frontiers in Ecology and Environment 11(7):348-354. http://dx.doi.org/10.1890/120333

Scasta, J. D., D. L. Lalman, and L. Henderson. 2016. Drought mitigation for grazing operations: matching the animal to the environment. Rangelands 38(4):204-210. http://dx.doi.org/10.1016/ j.rala.2016.06.006

Schwarzer, R. 2008. Modeling health behavior change: how to predict and modify the adoption and maintenance of health behaviors. Applied Psychology 57(1):1-29. http://dx.doi. org/10.1111/j.1464-0597.2007.00325.x

Sprinkle, J., C. Eppler, G. Ruyle, and D. Cook. 2012. NEPA for ranchers: applying the NEPA process on USFS and BLM rangelands for the authorization of livestock grazing. University of Arizona Cooperative Extension, Tucson, Arizona, USA. https:// extension.arizona.edu/sites/extension.arizona.edu/files/attachment/ gila-nepa-for-ranchers.pdf

Stern, M. J., and T. D. Baird. 2015. Trust ecology and the resilience of natural resource management institutions. Ecology and Society 20(2):14. http://dx.doi.org/10.5751/ES-07248-200214

Stern, M. J., C. A. Martin, S. A. Predmore, and W. C. Morse. 2014. Risk tradeoffs in adaptive ecosystem management: the case of the U.S. Forest Service. Environmental Management 53 (6):1095-1108. http://dx.doi.org/10.1007/s00267-014-0267-1

Stewart A. E. 2009. Psychological perspectives on adaptation to weather and climate. Pages 211-232 in K. L. Ebi, I. Burton, and G. MacGregor, editors. Biometeorology for adaptation to climate variability and change. Springer, New York, New York, USA. http://dx.doi.org/10.1007/978-1-4020-8921-3 10

Talley, J. L., J. Shneider, and E. Lindquist. 2016. A simplified approach to stakeholder engagement in natural resource management: the five-feature framework. Ecology and Society 21 (4):38. http://dx.doi.org/10.5751/ES-08830-210438

Tronstad, R., and D. Fuez. 2002. Impacts of the 2002 drought on western ranches and public land policies. Western Economics Forum 1(2):19-23. [online] URL: https://core.ac.uk/download/ pdf/6372604.pdf

United States Department of Agriculture, Forest Service (USDAFS). 2016. Rangeland management decisionmaking. In Forest Service handbook: grazing permit administration handbook. No. 2209.13-2016-1. Southwestern Region (Region 3). United States Department of Agriculture, Forest Service, Washington, D.C., USA.

von Korff, Y., K. A. Daniell, S. Moellenkamp, P. Bots, and R. M. Bijlsma. 2012. Implementing participatory water management: recent advances in theory, practice, and evaluation. Ecology and Society 17(1):30. http://dx.doi.org/10.5751/ES-04733-170130 
von Korff, Y., P. d'Aquino, K. A. Daniell, and R. Bijlsma. 2010. Designing participation processes for water management and beyond. Ecology and Society 15(3):1. http://dx.doi.org/10.5751/ ES-03329-150301

Weeks, D., P. Malone, and L. Welling. 2011. Climate change scenario planning: a tool for managing parks into uncertain futures. Park Science 28(1):Spring. [online] URL: https://www. cakex.org/sites/default/files/scenario-planning 0.pdf

Wilhite, D. A., M. V. K. Sivakumar, and R. Pulwarty. 2014. Managing drought risk in a changing climate: the role of national drought policy. Weather and Climate Extremes 3:4-13. http://dx. doi.org/10.1016/j.wace.2014.01.002

Wollenberg, E., D. Edmunds, and L. Buck. 2000. Using scenarios to make decisions about the future: anticipatory learning for the adaptive co-management of community forests. Landscape and Urban Planning 47:65-77. http://dx.doi.org/10.1016/S0169-2046 (99)00071-7

Wondolleck, J. M., and S. L. Yaffee. 2000. Making collaboration work: lessons from innovation in natural resource management. Island, Washington, D.C., USA. 
Appendix 1: Materials for and results of codevelopment activities.

Figure A1.1: Worksheet used during the group exercise for recording a solution to a drought scenario.

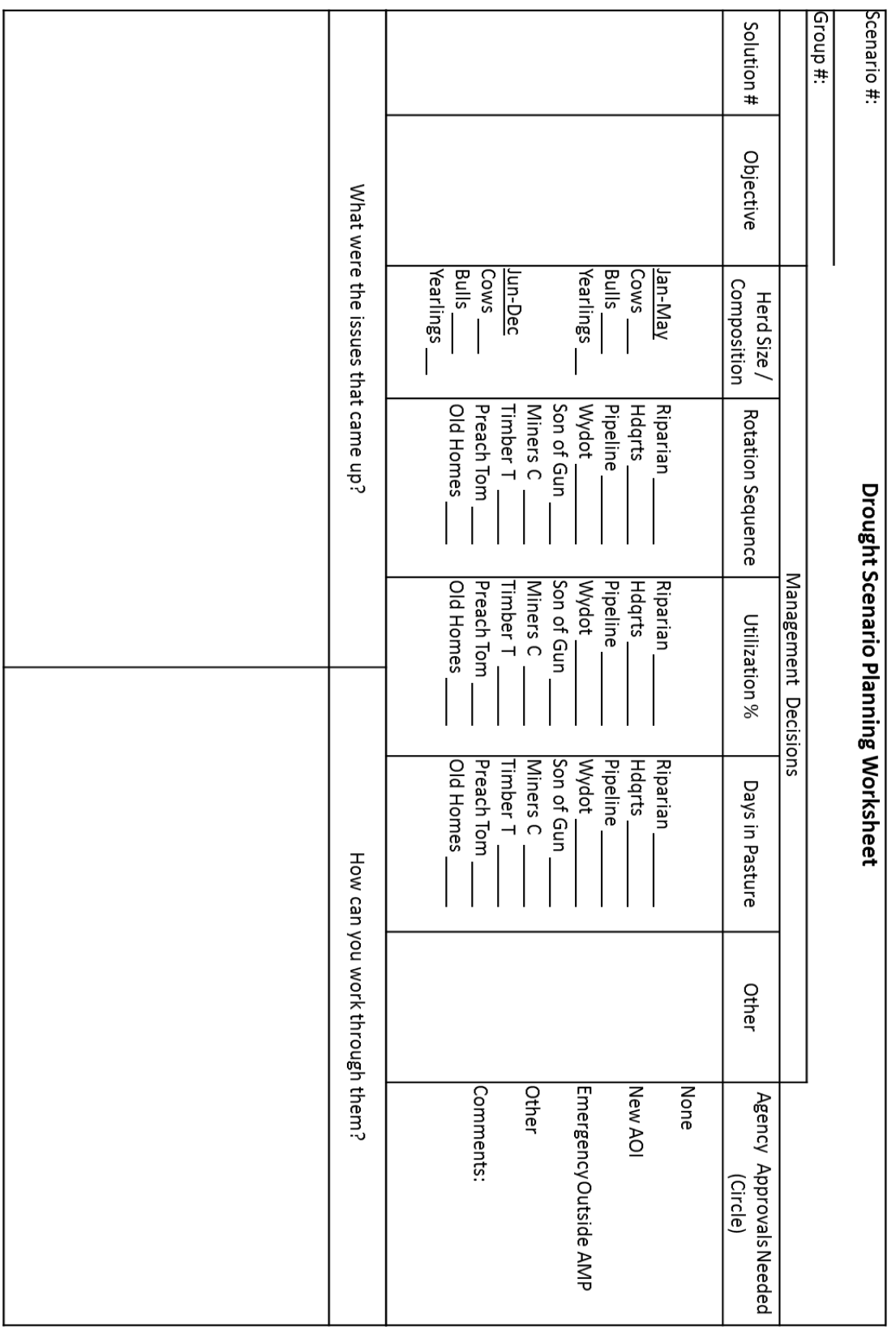


Table A1.1: Drought scenarios used for group exercises

\begin{tabular}{|c|c|c|c|}
\hline Scenario & $\begin{array}{l}\text { Drought Threat and Policy } \\
\text { Constraints }\end{array}$ & \# Solutions & Objectives \\
\hline A & $\begin{array}{l}\text { 1) } 1 \text { SPI winter to all } \\
\text { pastures }\end{array}$ & $\begin{array}{l}\text { Easy solution to } \\
\text { reduce use in each } \\
\text { pasture }\end{array}$ & $\begin{array}{l}\text { 1. Illustrates how the tool works } \\
\text { 2. Provides baseline for scenario } \\
\text { "B" }\end{array}$ \\
\hline B & $\begin{array}{l}\text { 1) Same as "A", and } \\
\text { 2) add policy constraint of } \\
\text { not grazing same dates as } \\
\text { previous year }\end{array}$ & $\begin{array}{l}\text { Many possible } \\
\text { solutions, but not } \\
\text { easy to solve }\end{array}$ & $\begin{array}{l}\text { 1. Illustrates how policy constraints } \\
\text { are applied } \\
\text { 2. Gives opportunity to begin } \\
\text { discussion about communication } \\
\text { between partners, and District } \\
\text { Ranger discretion }\end{array}$ \\
\hline $\mathrm{C}$ & $\begin{array}{l}\text { 1) } 1 \text { SPI winter for all } \\
\text { pastures, and } \\
\text { 2) } 1 \text { SPI summer for the } \\
\text { Miner's Camp, Timber } \\
\text { Top, Preacher Tom, and } \\
\text { Old Homestead pastures }\end{array}$ & $\begin{array}{l}\text { Many possible } \\
\text { solutions, none of } \\
\text { them simple. This } \\
\text { is likely to require } \\
\text { reducing animals, } \\
\text { feeding on private } \\
\text { land, or } \\
\text { negotiating for } \\
\text { variances and } \\
\text { other pastures. }\end{array}$ & $\begin{array}{l}\text { 1. This is performed with the entire } \\
\text { group, before breakout and lunch } \\
\text { 2. This illustrates the capacity of } \\
\text { the tool to develop solutions } \\
\text { 3. This illustrates the importance of } \\
\text { communication between } \\
\text { ranchers and Tonto. }\end{array}$ \\
\hline $\mathrm{D}$ & $\begin{array}{l}\text { 1) -1 SPI summer in } \\
\text { Preacher Tom, Old } \\
\text { Homestead, Miner's } \\
\text { Camp and Timber Top } \\
\text { pastures, } \\
\text { 2) No drinking water from } \\
\text { June through December in } \\
\text { Preacher Tom and Old } \\
\text { Homestead pastures } \\
\text { 3) No grazing 1 year after } \\
\text { fire in Old Homestead, } \\
\text { and } \\
\text { 4) No grazing Riparian } \\
\text { pasture May-September to } \\
\text { avoid conflict with heavy } \\
\text { recreation use. }\end{array}$ & $\begin{array}{l}\text { Many possible } \\
\text { solutions, none of } \\
\text { them simple. This } \\
\text { is likely to require } \\
\text { reducing animals, } \\
\text { feeding on private } \\
\text { land, or } \\
\text { negotiating for } \\
\text { variances and } \\
\text { other pastures. }\end{array}$ & $\begin{array}{l}\text { 1. This is performed by two of the } \\
4 \text { breakout groups. } \\
\text { 2. Requires group to work with the } \\
\text { tool. } \\
\text { 3. Can compare solutions between } \\
\text { the two groups. } \\
\text { 4. Intended to lead to long-term } \\
\text { discussion about making a road } \\
\text { and/or bring pipeline to Preacher } \\
\text { Tom pastures, } \\
\text { 5. Illustrates combination of } \\
\text { drought and policy constraints }\end{array}$ \\
\hline $\mathrm{E}$ & $\begin{array}{l}\text { 1) -1 SPI winter for all } \\
\text { pastures, } \\
\text { 2) No drinking water from } \\
\text { January through June in } \\
\text { Son of a Gun, Preacher } \\
\text { Tom, and Old Homestead } \\
\text { pastures } \\
\text { 3) No grazing } 1 \text { year after } \\
\text { fire in Miner's Camp and } \\
\text { Timber Top pastures. }\end{array}$ & $\begin{array}{l}\text { Many possible } \\
\text { solutions, none of } \\
\text { them simple. This } \\
\text { is likely to require } \\
\text { reducing animals, } \\
\text { feeding on private } \\
\text { land, or } \\
\text { negotiating for } \\
\text { variances and } \\
\text { other pastures. }\end{array}$ & $\begin{array}{l}\text { 1. This is performed by two of the } \\
4 \text { breakout groups. } \\
\text { 2. Requires group to work with the } \\
\text { tool. } \\
\text { 3. Can compare solutions between } \\
\text { the two groups. } \\
\text { 4. Intended to lead to long-term } \\
\text { discussion about making a road } \\
\text { and/or bring pipeline to Preacher } \\
\text { Tom pastures, }\end{array}$ \\
\hline
\end{tabular}




\begin{tabular}{|l|l|l|l|}
\hline & & $\begin{array}{l}\text { 5. Illustrates combination of } \\
\text { drought and policy constraints. }\end{array}$ \\
\hline
\end{tabular}




\section{Table A1.2: Solutions from Group Scenario-Planning Exercise}

\begin{tabular}{|c|c|c|c|c|}
\hline \multicolumn{5}{|c|}{ Scenario D Solutions } \\
\hline $\begin{array}{c}\mathfrak{\Xi} \\
\stackrel{0}{3}\end{array}$ & 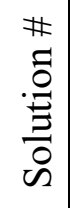 & Objectives & Practices & $\begin{array}{l}\text { Expected Forest Service Approval Type } \\
\text { (per practice number) }\end{array}$ \\
\hline 1 & 1 & $\begin{array}{ll}\text { - } & \text { Meet restriction dates } \\
\text { - } & \text { Minimize water hauling } \\
\text { - } & \text { Minimize herd reductions } \\
\text { - } & \text { Avoid grazing burned pasture } \\
\end{array}$ & $\begin{array}{l}\text { 1. Change pasture rotation } \$ \\
\text { 2. Sell } 70 \text { yearlings } \$ \\
\text { 3. Don't use pastures* without water }\end{array}$ & $\begin{array}{l}\text { 1-3. No new NEPA documentation } \\
\text { needed; DR approval to update AOI }\end{array}$ \\
\hline 1 & 2 & $\begin{array}{ll}\text { - } & \text { Meet restriction dates } \\
\text { - } & \text { Minimize water hauling } \\
\text { - } & \text { Minimize herd reductions } \\
\text { - } & \text { Manage burned pasture for positive } \\
\text { outcome }\end{array}$ & $\begin{array}{l}\text { 1. Change pasture rotation } \$ \\
\text { 2. Sell } 50 \text { yearlings } \$ \\
\text { 3. Haul water for } 15 \text { days at end of } \\
\text { year } \dagger \\
\text { 4. Increase utilization in a pasture to } \\
25 \% \ddagger \\
\text { 5. Use burned pasture during fire } \\
\text { recovery to promote soil health* }\end{array}$ & $\begin{array}{l}\text { 1-3. No new NEPA documentation } \\
\text { needed; DR approval to update AOI } \\
\text { 4-5. DR approval; inspection for } \\
\text { available forage; DR consults with } \\
\text { specialists. }\end{array}$ \\
\hline 1 & 3 & $\begin{array}{l}\text { - } \text { Meet restriction dates } \\
\text { - } \text { Minimize water hauling } \\
\text { - } \text { Minimize herd reductions } \\
\text { - } \quad \text { Yearlings available to sell as buffers }\end{array}$ & $\begin{array}{l}\text { 1. Change pasture rotation } \% \\
\text { 2. Reduce a pasture utilization to } 10 \% * \\
\text { 3. Permanent pipeline in pasture with } \\
\text { dry dirt tanks* }\end{array}$ & $\begin{array}{l}\text { 1-2. No new NEPA documentation; } \\
\text { DR approval to update AOI } \\
\text { 3. Small NEPA (CE) for } \\
\text { pipeline/trough outside of AMP. }\end{array}$ \\
\hline 2 & 1 & $\begin{array}{ll}\text { - } & \text { Meet restrictions imposed due to } \\
\text { drought } \\
\text { - } \\
\text { - } \text { Maintain herd size } \\
\text { - } \text { Maintain riparian and recreation } \\
\text { resource }\end{array}$ & 1. Change pasture rotation & $\begin{array}{l}\text { 1. May need updated AOI, depends on } \\
\text { timing. Will need to talk through it } \\
\text { with DR. }\end{array}$ \\
\hline
\end{tabular}




\begin{tabular}{|c|c|c|c|c|}
\hline 2 & 2 & $\begin{array}{ll} & \text { Meet restrictions imposed due to } \\
\text { drought } \\
\text { - } & \text { Maintain herd size } \\
\text { - } & \text { Workable rotation } \\
\text { - } & \text { Maintain riparian and recreation } \\
\text { - } & \text { Resource enhancement Miners' Camp } \\
& \text { pasture } \\
\end{array}$ & $\begin{array}{l}\text { 1. } \text { Change pasture rotation } \$ \\
\text { 2. Increase herd by } 30 \text { cows } \$ \\
\text { 3. Sell } 110 \text { yearlings in May } \$ \\
\text { 4. Provide supplemental feed in } \\
\text { headquarters pasture (private land; } 10 \\
\text { acres) for } 3 \text { days } \dagger\end{array}$ & $\begin{array}{l}\text { 1-4. No new NEPA documentation; } \\
\text { DR approval to update AOI }\end{array}$ \\
\hline 2 & 3 & $\begin{array}{ll}\text { - } & \text { Meet restrictions imposed due to } \\
\text { drought } \\
\text { - } & \text { Maintain herd size } \\
\text { - } & \text { Workable rotation } \\
\text { - } & \text { Maintain riparian and recreation } \\
& \text { resource }\end{array}$ & $\begin{array}{l}\text { 1. Haul water to a pasture for } 6 \text { weeks } \dagger \\
\text { 2. Plan for pipeline into two pastures* }\end{array}$ & $\begin{array}{l}\text { 1. No new NEPA documentation } \\
\text { needed; DR approval to update AOI; } \\
\text { trail through another pasture; phone } \\
\text { call when it happens } \\
\text { 2. Begin talking about update to AOI } \\
\text { and NEPA approval to update AMP } \\
\text { for pipeline and periodic grazing of } \\
\text { high elevation pastures }\end{array}$ \\
\hline 3 & 1 & $\begin{array}{l}\text { - } \quad \text { Maximize cows and utilization } \\
\text { - }\end{array}$ & $\begin{array}{l}\text { 1. Increase to } 300 \text { yearlings (assume } \\
\text { permit allows) } \$ \\
\text { 2. Sell all } 300 \text { yearlings in May } \$ \\
\text { 3. Need a couple days use to trail } \\
\text { through some pastures }\end{array}$ & $\begin{array}{l}\text { 1-3. No Forest Service approval } \\
\text { needed }\end{array}$ \\
\hline \multicolumn{5}{|c|}{ Scenario E Solutions } \\
\hline 产 & $\begin{array}{l}\# \\
\stackrel{0}{0} \\
\stackrel{0}{\Xi} \\
\dot{0} \\
\mathscr{n}\end{array}$ & Objectives & Practices & $\begin{array}{l}\text { Expected Forest Service Approval Type } \\
\text { (per practice number) }\end{array}$ \\
\hline 3 & 1 & $\begin{array}{l}\text { - } \quad \text { Reduce herd size as little as possible } \\
\text { - }\end{array}$ & $\begin{array}{l}\text { 1. } \text { Change pasture rotation }+ \\
\text { 2. Cull } 25 \text { open cows } \$ \\
\text { 3. Sell yearlingst } \$ \\
\text { 4. Haul water to a pasture for } 34 \text { days } \dagger \\
\text { 5. Temporary pipeline into a pasture } \dagger \\
\end{array}$ & $\begin{array}{l}\text { 1-3. No approval needed } \\
\text { 4-5. Archaeology clearance for } \\
\text { temporary waters } \\
\text { 6. NEPA for well site }\end{array}$ \\
\hline
\end{tabular}




\begin{tabular}{|c|c|c|c|c|}
\hline & & & $\begin{array}{l}\text { 6. Look at well site with pipeline off it } \\
\text { where the four pastures meet* }\end{array}$ & \\
\hline 4 & 1 & - Get through the year & $\begin{array}{l}\text { 1. Change pasture rotation } \$ \\
\text { 2. Sell } 70 \text { yearlings in fall; sell rest in } \\
\text { May } \$ \\
\text { 3. Haul water to a pasture for } 33 \text { days } \dagger\end{array}$ & $\begin{array}{l}\text { 1-3. No Forest Service approval } \\
\text { needed }\end{array}$ \\
\hline 4 & 2 & $\begin{array}{ll}\text { - } & \text { Reduce herd } \\
\text { - } & \text { (Least favorable solution) }\end{array}$ & $\begin{array}{l}\text { 1. Change pasture rotation } \ddagger \\
\text { 2. Reduce herd: sell } 25 \text { cows, } 2 \text { bulls, } \\
100 \text { yearlings in fall; sell rest of } \\
\text { yearlings in May } \ddagger \\
\text { 3. Extension of } 1-2 \text { days use in some } \\
\text { pastures } \dagger\end{array}$ & 1-3. Require negotiation with DR \\
\hline 4 & 3 & - Water improvements & $\begin{array}{l}\text { 1. Change pasture rotation } \$ \\
\text { 2. Water lot (corridor) into riparian } \\
\text { pasture from another pasture* } \\
\text { 3. Juniper treatment* } \\
\text { 4. Trick tank* } \\
\text { 5. Extend pipeline* } \\
\text { 6. Pipe from springs in high elevation } \\
\text { pasture to lower pasture* }\end{array}$ & $\begin{array}{l}\text { 1-5. Some of these could be approved } \\
\text { as an Emergency outside AMP } \\
\text { (because of fire) or done with a CE. } \\
\text { To do multiple projects would } \\
\text { require an EA. }\end{array}$ \\
\hline & & Tesponstive, & $\mathrm{AMP}=$ Allotment & Plan; $\mathrm{CE}=$ Cate \\
\hline
\end{tabular}




\section{Table A1.3: Decision Table for FS decision process for a water development}

AOI: Annual Operate Instruction; CE: Categorical Exclusion; Sect 18: NEPA Sufficiency; EA: Environmental Assessment; EIS:

Envir. Impact Statement

\begin{tabular}{|c|c|c|c|c|c|c|c|c|c|c|c|}
\hline \multirow{2}{*}{\begin{tabular}{|l} 
Table 1. \\
Characteristics
\end{tabular}} & \multicolumn{5}{|c|}{ Most likely Decision Type(s) } & \multicolumn{6}{|c|}{ Likely Length of Decision Process (Months) } \\
\hline & AOI & $\mathrm{CE}$ & Sect. 18 & EA & EIS & $<12$ & 12 & 24 & 36 & 48 & 60 \\
\hline 1. Previous NEPA Clearance & $\mathrm{X}$ & & $\mathrm{X}$ & & & $\mathrm{X}$ & & & & & \\
\hline 2. Possible legal challenge & & $\mathrm{X}$ & & & & $\mathrm{X}$ & $\mathrm{X}$ & & & & \\
\hline 3. Endangered species present (no effect) & & $\mathrm{X}$ & & & & $\mathrm{X}$ & $\mathrm{X}$ & & & & \\
\hline 4. Endangered species "take" & & & $\mathrm{X}$ & $\mathrm{X}$ & $\mathrm{X}$ & $\mathrm{X}$ & $\mathrm{X}$ & $\mathrm{X}$ & $\mathrm{X}$ & & \\
\hline 5. Recreational use conflict & & $\mathrm{X}$ & & $\mathrm{X}$ & & $\mathrm{X}$ & $\mathrm{X}$ & $\mathrm{X}$ & & & \\
\hline $\begin{array}{l}\text { 6. Multiple partners (private and/or govt) and beneficiaries (wildlife } \\
\text { and livestock) }\end{array}$ & & $\mathrm{X}$ & & & & $\mathrm{X}$ & $\mathrm{X}$ & & & & \\
\hline 7. Cultural resources present & & $\mathrm{X}$ & & & & & $\mathrm{X}$ & & & & \\
\hline 8. FS staffing is reduced & & $\mathrm{X}$ & & & & & $\mathrm{X}$ & $\mathrm{X}$ & & & \\
\hline 9. FS funding priority is low & & $\mathrm{X}$ & & & & & $\mathrm{X}$ & $\mathrm{X}$ & $\mathrm{X}$ & & \\
\hline 10. New District Ranger (inexperienced) & & & & & & & & $\mathrm{X}$ & $\mathrm{X}$ & & \\
\hline $\begin{array}{l}\text { 11. Precisely engineered project design at the beginning (No impact } \\
\text { and complete design) }\end{array}$ & & $\mathrm{X}$ & & & & $\mathrm{X}$ & & & & & \\
\hline 12. Upcoming NEPA scheduled within 3 years (added in discussion) & & & & & & & & & & $\mathrm{X}$ & $\mathrm{X}$ \\
\hline 13. “5-year Drought Plan” prepared (added in discussion) & & & & & & $\mathrm{X}$ & $\mathrm{X}$ & & & & \\
\hline 14. Grouping projects (Multiple allotments) (added in discussion) & & & & & & & & & & & \\
\hline
\end{tabular}


Figure A1.2: Example of completed Worksheet for an EA (Environmental Assessment): Develop spring in "Son of a Gun" to deliver water to other pastures

\begin{tabular}{|c|c|c|c|c|c|c|c|}
\hline \multicolumn{3}{|c|}{$\begin{array}{l}\text { Scenario: Develop spring in "Son of a Gun" pasture to } \\
\text { deliver water to other pastures }\end{array}$} & Group \#: & \multicolumn{4}{|c|}{ Group Members: } \\
\hline \multicolumn{4}{|c|}{$\begin{array}{l}\text { Characteristics } \\
1 . \\
2 . \\
3 .\end{array}$} & \multicolumn{2}{|c|}{$\begin{array}{l}\text { Decision-type } \\
\text { Assigned as either CE, EA Sect. } \\
\text { 18, or EIS } \\
\qquad \text { EA }\end{array}$} & \multicolumn{2}{|c|}{$\begin{array}{l}\text { Likely Duration } \\
\text { In Months }\end{array}$} \\
\hline $\begin{array}{l}\text { Steps in the } \\
\text { Decision- } \\
\text { Process }\end{array}$ & $\begin{array}{l}\text { \# of Months } \\
6-12 \ldots\end{array}$ & $\begin{array}{l}\text { \# of Months } \\
1-3 \\
\end{array}$ & & $\begin{array}{c}\text { \# of Months } \\
6-12 \\
\end{array}$ & $\begin{array}{c}\text { \# of Mo } \\
2 \\
\end{array}$ & & $\begin{array}{c}\text { \# of Months } \\
2 \\
\end{array}$ \\
\hline $\begin{array}{l}\text { What is } \\
\text { likely to } \\
\text { happened } \\
\text { and when }\end{array}$ & $\begin{array}{l}\text { - Pre-design } \\
\text { NEPA } \\
\text { - What is there, } \\
\text { and close } \\
\text { scoping } \\
\text { - Specialist's } \\
\text { input }\end{array}$ & $\begin{array}{l}\text { - Scoping, } \\
\text { Notice, and } \\
\text { Public } \\
\text { Comments }\end{array}$ & $\begin{array}{r}\text { - } \mathrm{A} \\
\mathrm{S} \\
\mathrm{R} \\
\text { - } \mathrm{R} \\
\mathrm{C}\end{array}$ & $\begin{array}{l}\text { Analysis and } \\
\text { Specialist } \\
\text { Review } \\
\text { Respond to } \\
\text { Comments }\end{array}$ & $\begin{array}{l}\text { - } \text { Draft d } \\
\text { - Objecti } \\
\text { Period }\end{array}$ & cision & $\begin{array}{l}\text { - Resolve } \\
\text { objections }\end{array}$ \\
\hline
\end{tabular}




\section{Figure 2 continued: Example of reverse page of Worksheet}

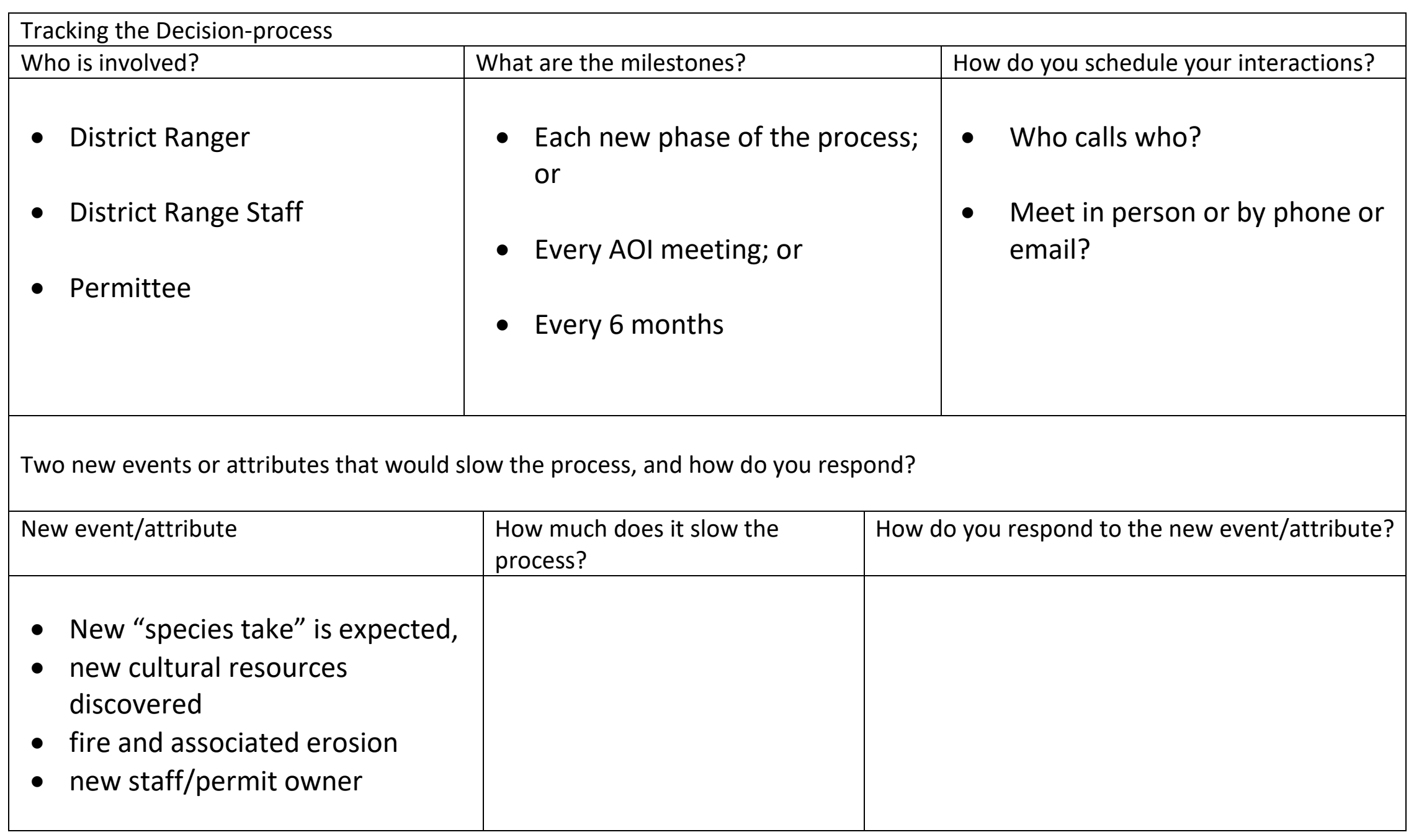

